\title{
A 1500-year multiproxy record of coastal hypoxia from the northern Baltic Sea indicates unprecedented deoxygenation over the 20th century
}

\author{
Sami A. Jokinen ${ }^{1}$, Joonas J. Virtasalo ${ }^{2}$, Tom Jilbert ${ }^{3}$, Jérôme Kaiser ${ }^{4}$, Olaf Dellwig ${ }^{4}$, Helge W. Arz ${ }^{4}$, Jari Hänninen ${ }^{5}$, \\ Laura Arppe $^{6}$, Miia Collander ${ }^{7}$, and Timo Saarinen ${ }^{1}$ \\ ${ }^{1}$ Department of Geography and Geology, University of Turku, 20014 Turku, Finland \\ ${ }^{2}$ Marine Geology, Geological Survey of Finland (GTK), P.O. Box 96, 02151 Espoo, Finland \\ ${ }^{3}$ Department of Environmental Sciences, University of Helsinki, P.O. Box 65, 00014 Helsinki, Finland \\ ${ }^{4}$ Leibniz Institute for Baltic Sea Research Warnemünde (IOW), Seestrasse 15, 18119 Rostock, Germany \\ ${ }^{5}$ Archipelago Research Institute, University of Turku, 20014 Turku, Finland \\ ${ }^{6}$ Finnish Museum of Natural History, University of Helsinki, P.O. Box 64, 00014 Helsinki, Finland \\ ${ }^{7}$ Department of Food and Environmental Sciences, University of Helsinki, P.O. Box 66, 00014 Helsinki, Finland
}

Correspondence: Sami A. Jokinen (sami.jokinen@utu.fi)

Received: 12 January 2018 - Discussion started: 16 January 2018

Revised: 1 June 2018 - Accepted: 6 June 2018 - Published: 5 July 2018

\begin{abstract}
The anthropogenically forced expansion of coastal hypoxia is a major environmental problem affecting coastal ecosystems and biogeochemical cycles throughout the world. The Baltic Sea is a semi-enclosed shelf sea whose central deep basins have been highly prone to deoxygenation during its Holocene history, as shown previously by numerous paleoenvironmental studies. However, long-term data on past fluctuations in the intensity of hypoxia in the coastal zone of the Baltic Sea are largely lacking, despite the significant role of these areas in retaining nutrients derived from the catchment. Here we present a 1500-year multiproxy record of near-bottom water redox changes from the coastal zone of the northern Baltic Sea, encompassing the climatic phases of the Medieval Climate Anomaly (MCA), the Little Ice Age (LIA), and the Modern Warm Period (MoWP). Our reconstruction shows that although multicentennial climate variability has modulated the depositional conditions and delivery of organic matter (OM) to the basin the modern aggravation of coastal hypoxia is unprecedented and, in addition to gradual changes in the basin configuration, it must have been forced by excess human-induced nutrient loading. Alongside the anthropogenic nutrient input, the progressive deoxygenation since the beginning of the 1900s was fueled by the combined effects of gradual shoaling of the basin and warming climate, which amplified sediment focusing and increased
\end{abstract}

the vulnerability to hypoxia. Importantly, the eutrophication of coastal waters in our study area began decades earlier than previously thought, leading to a marked aggravation of hypoxia in the $1950 \mathrm{~s}$. We find no evidence of similar anthropogenic forcing during the MCA. These results have implications for the assessment of reference conditions for coastal water quality. Furthermore, this study highlights the need for combined use of sedimentological, ichnological, and geochemical proxies in order to robustly reconstruct subtle redox shifts especially in dynamic, non-euxinic coastal settings with strong seasonal contrasts in the bottom water quality.

\section{Introduction}

The expansion of hypoxic dead zones is an ongoing global problem both in the marine realm (Diaz and Rosenberg, 2008; Vaquer-Sunyer and Duarte, 2008; Gooday et al., 2009; Rabalais et al., 2010, 2014) and in lacustrine settings (Jenny et al., 2016a, b). Bottom water oxygen depletion $\left(<2 \mathrm{mg} \mathrm{L}^{-1}\right.$ dissolved oxygen), caused by the combined effects of water column stratification and excess delivery of organic matter (OM) to the seafloor, deteriorates benthic ecosystems (Levin et al., 2009) and often triggers harmful algal blooms (Zhang 
et al., 2010) due to the impact of hypoxia on biogeochemical cycles at the sediment-water interface (Middelburg and Levin, 2009). Upon bottom water deoxygenation, phosphorus $(\mathrm{P})$ is released efficiently to the water column from surface sediments, fueling further primary productivity and dinitrogen $\left(\mathrm{N}_{2}\right)$ fixation by diazotrophic cyanobacteria, thus triggering a self-sustaining positive feedback mechanism commonly associated with eutrophication (Vahtera et al., 2007). In addition, the ability of benthic ecosystems to remove nitrogen via denitrification and anaerobic ammonium oxidation may be reduced upon repeated or prolonged exposure to bottom water hypoxia (Conley et al., 2009a; Middelburg and Levin, 2009; Carstensen et al., 2014b). Due to these internal feedback mechanisms, recovery from hypoxia is often slow, hampering management of the problem through reductions in external nutrient loading (Vahtera et al., 2007). Furthermore, global warming is likely to exacerbate the spreading of hypoxia in many regions through enhanced nutrient inputs (linked to increased precipitation and discharge), decreased solubility of oxygen due to increased temperature, and acceleration of internal nutrient cycling (Meier et al., 2011; Meire et al., 2013).

Over the past century, the Baltic Sea has seen a marked expansion of benthic hypoxia (Jonsson et al., 1990; Conley et al., 2011; Carstensen et al., 2014a), and the Baltic Sea dead zone is often referred to as the largest anthropogenically induced hypoxic marine area in the world (Diaz and Rosenberg, 2008). Yet, although long-term trends in the expansion of hypoxia in offshore areas of the Baltic Sea have been widely studied, little is known about the past evolution of hypoxia in the shallow coastal areas, where episodic or seasonal oxygen deficiency is forced by thermal rather than salinity stratification (Virtasalo et al., 2005; Conley et al., 2011). Importantly, these coastal areas act as a filter for nutrients received from the catchment (Asmala et al., 2017). Thus, changes in biogeochemical cycles in coastal sediments may have an impact on nutrient transport to offshore areas of the Baltic Sea (Almroth-Rosell et al., 2016). Elucidating fluctuations in coastal hypoxia will aid in the understanding of the efficiency of the coastal filter and is therefore vital for understanding the expansion of hypoxia in the entire Baltic Sea. Indeed, it is still debated whether the decisive factor triggering the hypoxic event during the Medieval Climate Anomaly (MCA, 900-1350 AD) in the Baltic Proper was intensified land use in the catchment (Zillén and Conley, 2010) or anomalously warm climate (Kabel et al., 2012; Papadomanolaki et al., 2018).

In this study, we present a multiproxy reconstruction of the development of hypoxia in an enclosed coastal setting in the Finnish Archipelago Sea (northern Baltic Sea) over the past 1500 years, covering the known climatic oscillations of the MCA, the Little Ice Age (LIA, 1350-1850 AD), and the Modern Warm Period (MoWP, after 1850 AD) in order to assess how the coastal zone responds to centennial-millennial climate variability and potential past inputs of nutrients from the catchment areas. We use diverse bulk sediment geochemical proxies in combination with integrated sedimentological and ichnological analyses to elucidate temporal changes in the intensity of near-bottom water oxygen deficiency. In order to constrain the drivers behind the observed oxygenation changes, we assess past fluctuations in hydrodynamic conditions at the study site, and in the delivery of OM, and compare these with the past climate variability and changes in the anthropogenic nutrient loading from the catchment.

\section{Study location}

The Baltic Sea is a shallow (mean depth $54 \mathrm{~m}$ ) semi-enclosed basin located on a continental shelf (Fig. 1a) between maritime temperate and continental sub-Arctic climate zones. Climatic conditions in the area are largely modulated by the North Atlantic Oscillation (NAO) as well as the summer low and winter high over Eurasia (e.g., Rutgersson et al., 2014). Winter mean air temperature ranges from $-12^{\circ} \mathrm{C}$ in the north to $0^{\circ} \mathrm{C}$ in the south, whereas summer mean temperature has a narrower range of $14-17^{\circ} \mathrm{C}$. The sea is essentially nontidal, but irregular variations in wind and atmospheric pressure modulate the water level with a maximum amplitude of $2 \mathrm{~m}$.

Surface salinity exhibits an increasing trend from north to south, from 3-5 in the Gulf of Finland and Gulf of Bothnia to 8-10 in the southern Baltic (Leppäranta and Myrberg, 2009). This horizontal salinity gradient results from combined effects of high riverine freshwater input in the north and occasional inflows of saline water from the North Sea through the Danish straits in the south. The contrasting density of these two water masses leads to the formation of a strong $10-20 \mathrm{~m}$ thick pycnocline, which lies at a depth of 40-80 $\mathrm{m}$ depending on the sub-basin (Leppäranta and Myrberg, 2009). Irregular saline inflow events from the North Sea occasionally ventilate the deep stagnant bottom waters of the Baltic Proper, but this oxygen is readily exhausted with a net effect of stronger stratification and possibly even more severe oxygen depletion (Conley et al., 2002; Carstensen et al., 2014a).

The Archipelago Sea, located in the southwestern coastal area of Finland in the northern Baltic Sea (Fig. 1a), is a mosaic of thousands of islands and small bays within an area of $\sim 8000 \mathrm{~km}^{2}$. Salinity in the area ranges from 5 to 7 , increasing towards the open sea. Mean water depth is only $23 \mathrm{~m}$, although some depths reach over $100 \mathrm{~m}$. The length of the ice season is 3-4.5 months (Seinä, 1994), but a current decreasing trend of 46 days per century has been reported (Ronkainen, 2013). The rate of the present glacio-isostatic uplift is 3-4 mm per year (Mäkinen and Saaranen, 1998), which exposes previously deposited sediments to wave erosion and modulates hydrographic conditions in the area.

The complex topography of the Archipelago Sea results in restricted water exchange between the inner archipelago and the open-sea areas (Mälkki et al., 1979), and numerous small 


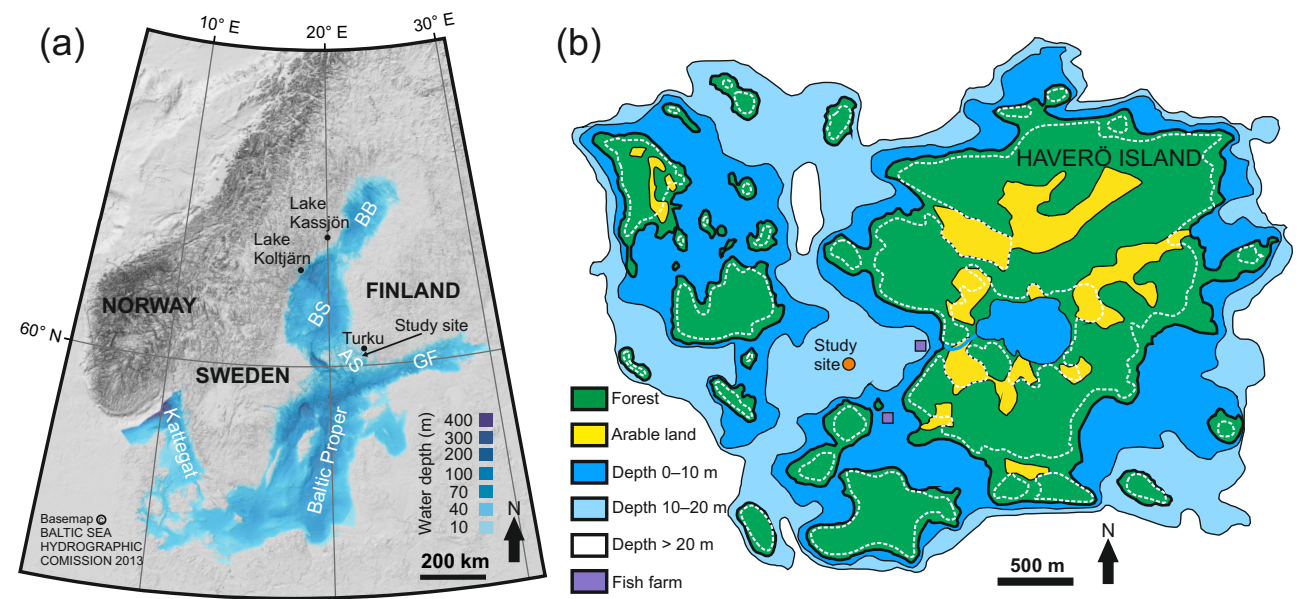

Figure 1. Maps of the study area. (a) Bathymetric map of the Baltic Sea. The abbreviations for the indicated sub-basins are as follows: BB, Bothnian Bay; BS, Bothnian Sea; AS, Archipelago Sea; GF, Gulf of Finland. Locations of the varved lakes used for the correlation of the pollution $\mathrm{Pb}$ profiles are also shown. (b) Inset map of the study location. White dashed line indicates the $5 \mathrm{~m}$ contour line that roughly corresponds to the paleoshoreline at $\sim 760 \mathrm{AD}$.

basins with contrasting bottom water conditions exist in close proximity (Virtasalo et al., 2005). Water exchange in the area mostly occurs through deep straits following the fault-lines of the crystalline bedrock, which are mostly aligned in a north-south direction. In enclosed basins, a strong thermocline impedes mixing of dissolved oxygen to the bottom waters during summer, which together with high delivery of reactive $\mathrm{OM}$ to the seafloor commonly results in seasonal hypoxia (Virtasalo et al., 2005; Jokinen et al., 2015). Mixing of the water column through thermal convection takes place in spring and autumn due to the lack of a permanent halocline (Leppäranta and Myrberg, 2009).

The sediment fill of the Archipelago Sea since the deglacial to present comprises a succession of ice-proximal tills and outwash, glaciolacustrine rhythmites, patchily distributed debrites, postglacial lacustrine clays, and brackishwater mud drifts (Virtasalo et al., 2007, 2014). The study area was deglaciated at $\sim 11400 \mathrm{cal} \mathrm{BP}$ (Stroeven et al., 2016), which led to freshwater conditions in the area (Tuovinen et al., 2008). By $\sim 7600 \mathrm{cal} B$ B, the eustatic ocean-level rise surpassed the glacio-isostatic rebound rate and the Danish straits became inundated, resulting in marine flooding of the Baltic Sea basin and consequent salinization of the Archipelago Sea (Tuovinen et al., 2008). Since then, sedimentation in the Archipelago Sea has been characterized by wave and current modulated deposition of brackish-water mud drifts with laminated intervals and local unconformities (Virtasalo et al., 2007).

Haverö is a small, extremely enclosed basin in the middle of the Archipelago Sea (Fig. 1). The Proterozoic bedrock surface in the area is dominated by microcline granites, with small patches of gneisses, amphibolite, and granodiorite (Bedrock of Finland, DigiKP). Due to the relatively high elevation of the surrounding islands, Quaternary deposits have been largely removed by erosion after the islands were uplifted above the wave base (Maankamara, DigiKP). The distance to the mouths of the largest rivers in the area, Aurajoki River and Paimionjoki River, is 25 and $38 \mathrm{~km}$, respectively. A small brook drains into the basin from a lake located on the Haverö island. Sedimentation in the Haverö basin is dominated by reworking of previously deposited late- and postglacial clays and organic-rich brackish-water muds during autumn and winter, and by rapid settling of organic-rich aggregates during spring and summer (Jokinen et al., 2015). This seasonal contrast in the sedimentation, accompanied by severe seasonal hypoxia and consequent deterioration of macrobenthic fauna, has enabled the formation and preservation of annual laminations (varves) over the past decades (Jokinen et al., 2015). Population around Haverö is sparse, and the dominant direct anthropogenic nutrient loading is sourced from two local fish farming cages that were operational from 1987 to 2008 AD (Fig. 1b).

\section{Description of the proxies}

\subsection{Proxies for hydrodynamic conditions}

\subsubsection{Sediment grain size}

Sediment grain size depends on sediment inputs and hydrodynamic conditions. Given that sediment provenance remains fixed, temporal variation in grain size distribution in the coastal zone of the Baltic Sea, excluding river mouths, is mainly governed by changes in wind stress and local seafloor morphometry that modulate the bottom water energy flux (Lehmann et al., 2002b; Jönsson et al., 2005a; Ning et al., 2016). In general, periods with enhanced near-bottom cur- 
rents become recorded in sediments through increased proportion of coarse grains (e.g., Hjulström, 1939).

\subsubsection{Titanium to potassium ratio}

In fine-grained sediments, potassium $(\mathrm{K})$ is mainly associated with illite $\left(\left(\mathrm{K}, \mathrm{H}_{3} \mathrm{O}\right)(\mathrm{Al}, \mathrm{Mg}, \mathrm{Fe})_{2}(\mathrm{Si}, \mathrm{Al})_{4} \mathrm{O}_{10}\left[(\mathrm{OH})_{2}\left(\mathrm{H}_{2} \mathrm{O}\right)\right]\right)$,

whereas titanium (Ti) is mainly present in heavy minerals such as rutile $\left(\mathrm{TiO}_{2}\right)$ or ilmenite $\left((\mathrm{Fe}, \mathrm{Mg}, \mathrm{Mn}, \mathrm{Ti}) \mathrm{O}_{3}\right)$ and thus it concentrates in the coarse fraction of sediments due to sorting effects (Dellwig et al., 2000). Therefore, variations in $\mathrm{Ti} / \mathrm{K}$ in locations with negligible changes in sediment provenance over time can be ascribed to changes in depositional energy and sediment transport processes (Piva et al., 2008; Spofforth et al., 2008), whereby an increase in the ratio denotes amplified bottom water currents.

\subsection{Proxies for the source of organic matter}

\subsubsection{Carbon to nitrogen ratio}

Due to the contrasting composition of vascular plants in comparison to phytoplankton, carbon $(\mathrm{C})$ to nitrogen $(\mathrm{N})$ ratios of sediment OM can be used to estimate relative contributions of OM originating from terrestrial and marine compartments (Meyers, 1994, 1997, and references therein). This difference arises from the high abundance of proteins in algae, while vascular plants are rich in cellulose instead. Accordingly, marine and terrestrial $\mathrm{OM}$ are characterized by molar $\mathrm{C} / \mathrm{N}$ ratios of 4-10 and >20, respectively. However, C / N of OM produced in the euphotic zone is potentially elevated during sinking (Müller, 1977; Meyers, 2003) and diagenesis (Gälman et al., 2008) due to preferential degradation of $\mathrm{N}$ over $\mathrm{C}$. Conversely, adsorption of ammonia (produced upon OM decomposition) onto clay mineral surfaces has the potential to decrease sediment $\mathrm{C} / \mathrm{N}$ during diagenesis, especially in sediments with less than $0.3 \%$ of $\mathrm{C}_{\text {org }}$ (Müller, 1977). Despite these potential constraints, the $\mathrm{C} / \mathrm{N}$ ratio often accurately records past variations in the source of $\mathrm{OM}$ to the seafloor (Meyers, 1994; 1997), as suggested for the coastal Baltic Sea (Müller and Mathesius, 1999).

\subsubsection{Stable isotope composition of carbon}

Stable isotope composition of sediment organic carbon $\left(\delta^{13} \mathrm{C}_{\text {org }}\right)$ depends on the isotopic ratio of the $\mathrm{C}$ source as well as on the fractionation between ${ }^{12} \mathrm{C}$ and ${ }^{13} \mathrm{C}$ during photosynthesis (e.g., Hayes, 1993). A vast majority of plants present in the study area fix $\mathrm{C}$ via the Calvin $\left(\mathrm{C}_{3}\right)$ pathway, whereby ${ }^{12} \mathrm{C}$ is preferentially incorporated, producing $\mathrm{C}_{\text {org }}$ with $20 \%$ lighter isotope composition than the inorganic $\mathrm{C}$ $\left(\mathrm{C}_{\text {inorg }}\right)$ source. Land plants use atmospheric carbon dioxide $\left(\mathrm{CO}_{2}, \delta^{13} \mathrm{C} \sim-7 \%\right.$ ) as their source of $\mathrm{C}_{\text {inorg }}$, whereas marine algae utilize dissolved bicarbonate $\left(\mathrm{HCO}_{3}^{-}, \delta^{13} \mathrm{C} \sim 0 \%\right.$ o) in addition to $\mathrm{CO}_{2}$, resulting in higher $\delta^{13} \mathrm{C}$ values in marine phytoplankton. Although the preferential source of $\mathrm{C}$ for marine algae is dissolved $\mathrm{CO}_{2}$, they incorporate a progressively higher proportion of $\mathrm{HCO}_{3}^{-}$with respect to $\mathrm{CO}_{2}$ under decreasing $p \mathrm{CO}_{2}$ (Fogel et al., 1992; Rost et al., 2003), leading to increasing $\delta^{13} \mathrm{C}$ values in their cells. Accordingly, organic matter produced by land plants has an average $\delta^{13} \mathrm{C}$ value of $\sim-27 \%$, whereas phytoplankton-derived marine organic matter is characterized by a $\delta^{13} \mathrm{C}$ signature from -20 to $-22 \%$ o (Meyers, 1994). Although early diagenetic processes potentially alter the original stable isotope composition of OM (Lehmann et al., 2002a), a number of studies indicate that the $\delta^{13} \mathrm{C}$ signature of sediment $\mathrm{OM}$ often robustly records past environmental changes in the water column (Meyers, 1994, 1997; Freudenthal et al., 2001; Kohzu et al., 2011).

\subsubsection{Stable isotope composition of nitrogen}

The stable isotope composition of nitrogen $\left(\delta^{15} \mathrm{~N}\right)$ in marine OM produced in the euphotic zone is governed by the isotopic ratio of nitrate $\left(\mathrm{NO}_{3}^{-}\right)$and the extent to which this nutrient reservoir is consumed by phytoplankton (Altabet and Francois, 1994; Voss et al., 1996). Due to the preferential assimilation of ${ }^{14} \mathrm{NO}_{3}^{-}$during photosynthesis, the produced $\mathrm{OM}$ is depleted in ${ }^{15} \mathrm{~N}$ relative to the inorganic $\mathrm{N}$ source. If the available nutrient pool is not continuously replenished (e.g., due to thermal stratification), the $\delta^{15} \mathrm{~N}$ signature of the remaining $\mathrm{NO}_{3}^{-}$pool becomes progressively enriched following Rayleigh fractionation kinetics (Altabet and Francois, 1994). Consequently, upon complete exhaustion of the $\mathrm{NO}_{3}^{-}$ pool due to a period of intensive primary productivity, such as a spring bloom, no net isotopic fractionation occurs and the "original" $\delta^{15} \mathrm{~N}$ signature of $\mathrm{NO}_{3}^{-}$is communicated to the accumulated OM. On continental margin settings characterized by high sedimentation rates and intensive phytoplankton blooms that contribute the majority of OM delivery to the seafloor, as in the Baltic Sea, alteration of the primary $\delta^{15} \mathrm{~N}$ signal attained by phytoplankton within the euphotic zone is minute both during sinking through the water column (Altabet et al., 1991; Altabet and Francois, 1994) and during early diagenesis (Kienast et al., 2002; Thunell et al., 2004). Hence, high $\delta^{15} \mathrm{~N}$ values in coastal sediments often record eutrophication through agricultural and urban contribution to riverine $\mathrm{N}$ loading (McClelland and Valiela, 1998; Voss et al., 2000, 2005; Struck et al., 2000; Cole et al., 2004), owing to the enrichment of ${ }^{15} \mathrm{~N}$ in fertilizer and manure due to $\mathrm{N}$ transformations such as denitrification and ammonia volatilization in catchment soils (Heaton, 1986; Aravena et al., 1993).

\subsubsection{Branched isoprenoid tetraether index}

Founded on the observation that branched glycerol dialkyl glycerol tetraethers (GDGTs I-III) are mainly sourced from terrestrial environment (soil OM), whereas crenarchaeol originates predominantly from the marine environment (a 
characteristic lipid for aquatic Thaumarchaeota), Hopmans et al. (2004) defined the branched isoprenoid tetraether (BIT) index as a proxy for the relative abundance of terrestrial OM:

BIT index $=$

$\frac{[\text { GDGT }- \text { I }]+[\text { GDGT }- \text { II }]+[\text { GDGT }- \text { III }]}{[\text { Crenarchaeol }]+[\text { GDGT }- \text { I }]+[\text { GDGT }- \text { II }]+[\text { GDGT }- \text { III }]}$,

where end-member values of 0 and 1 denote open marine and coastal environment, respectively. Diagenetic effects on the BIT index are regarded as minute due to the structural similarity of the compounds involved (Schouten et al., 2013). Possible constraints on the application of the BIT index include potential in situ production of branched GDGTs in the water column (Sinninghe Damsté et al., 2009) and marine sediments (Peterse et al., 2009) as well as the potential production of crenarchaeol in soils (Weijers et al., 2006).

\subsection{Redox proxies}

\subsubsection{Sedimentary fabric}

Sedimentary-fabric analysis is focused on the preservation of primary sedimentary structure, its mixing by macrofaunal bioturbation, and the characteristics of identifiable bioturbation structures (trace fossils). Trace fossil assemblages of the organic-rich brackish-water muds of the Baltic Sea are well applicable for reconstructing past bottom water redox shifts (Virtasalo et al., 2011a, b). Benthic faunal responses to bottom water hypoxia include avoidance or even mortality of large species, loss of diversity, and shoaling of penetration depth or emergence from sediment (Levin et al., 2009). Consequently, the vertical extent, diameter, and diversity of burrows constructed by macrobenthic fauna decrease with declining bottom water oxygenation, which is thought to be the decisive factor shaping biogenic sedimentary fabrics in the Baltic Sea (Savrda and Bottjer, 1986, 1991; Virtasalo et al., 2011a, b), although other factors such as salinity, substrate consistency, and food supply also affect trace fossil assemblages in the area (Virtasalo et al., 2006, 2011a). Importantly, the behavior of macrobenthic fauna responds rapidly to changes in the bottom water environmental conditions, and these responses can be readily recorded in the trace fossil assemblages (Savrda and Bottjer, 1986; Wetzel, 1991). The magnitude of this response is governed by the intensity and duration the deoxygenation as well as by the recovery time between consecutive hypoxic events (Levin et al., 2009).

\subsubsection{Molybdenum content}

Sedimentary molybdenum (Mo) content is a well-established proxy for past redox fluctuations in bottom waters overlying marine sediments (e.g., Algeo and Lyons, 2006; Scott and Lyons, 2012; Helz and Adelson, 2013). It has been successfully applied to Baltic Sea sediments for bottom water redox reconstructions, especially in deep areas (Mort et al.,
2010; Jilbert and Slomp, 2013; Jilbert et al., 2015; Dijkstra et al., 2016; Hardisty et al., 2016; van Helmond et al., 2017). The sensitivity of sedimentary Mo content to redox fluctuations is due to the conversion of the relatively inert molybdate ion $\left(\mathrm{MoO}_{4}^{2-}\right)$ in seawater to a series of particlereactive thiomolybdates $\left(\mathrm{MoO}_{x} \mathrm{~S}_{4-x}\right)$ under exposure to hydrogen sulfide $\left(\mathrm{H}_{2} \mathrm{~S}\right)$. Where the concentration of $\mathrm{H}_{2} \mathrm{~S}_{\mathrm{aq}}$ exceeds $\sim 11 \mu \mathrm{M}$, the so-called sulfide switch is activated and a quantitative conversion to tetrathiomolybdate $\mathrm{MoS}_{4}^{2-}$ may occur (Helz et al., 1996; Erickson and Helz, 2000), triggering effective fixation of Mo in association with $\mathrm{Fe}-\mathrm{S}$ phases (Helz et al., 1996, 2011; O'Connor et al., 2015) and organic matter (Helz et al., 1996; Algeo and Lyons, 2006; Dahl et al., 2017). In addition, Mo is reduced from oxidation state (VI) to (IV) during burial in sediments (Dahl et al., 2013). Under non-euxinic conditions, where $\mathrm{H}_{2} \mathrm{~S}$ is only found in pore waters but not in bottom waters, the initial sedimentation of water column Mo often occurs through adsorption to solidphase manganese $(\mathrm{Mn})$ oxides at the sediment-water interface (Scott and Lyons, 2012; Scholz et al., 2013; Noordmann et al., 2015). Upon reduction of Mn oxides, Mo is released into the pore waters, from where it may efflux back to the water column or become sequestered into the sediments in the presence of sufficiently high sulfide levels. In such settings, the depth and intensity of the pore water $\mathrm{H}_{2} \mathrm{~S}$ maximum (in Baltic Sea sediments typically associated with the sulfate-methane transition zone (SMTZ), Egger et al., 2015; Jilbert et al., 2018) is expected to regulate the amount of Mo sequestered in the sediment (Adelson et al., 2001; Scott and Lyons, 2012; Helz and Adelson, 2013; Sulu-Gambari et al., 2017).

\subsubsection{Pristane to phytane ratio}

The application of the pristane to phytane ratio $(\mathrm{Pr} / \mathrm{Ph})$ as a redox proxy is based on the theory that both of these aliphatic hydrocarbons are mainly sourced from the phytol side chain of chlorophylls, with preferential diagenetic formation of $\mathrm{Ph}$ upon exposure to reducing conditions (Didyk et al., 1978). Didyk et al. (1978) postulated that $\mathrm{Pr} / \mathrm{Ph}$ ratios of $<1$ are indicative of deposition under anoxic water column, while ratios fluctuating about 1 record oscillations between anoxic and oxic bottom waters, and persistently oxic bottom waters result in ratios $>1$. However, it has been shown that a decline in $\mathrm{Pr} / \mathrm{Ph}$ may also be caused by excess production of $\mathrm{Ph}$ sourced from methanogenic microbes below the SMTZ (Brassel et al., 1981; Venkatesan and Kaplan, 1987; Duan, 2000). As a result, the ratio should be used cautiously and in association with other indicators of redox conditions. This redox proxy is widely used in petroleum geology to characterize source rocks (Peters et al., 2005) but is so far unutilized in studies of Baltic Sea sediments. 


\section{Materials and methods}

\subsection{Sediment coring, subsampling, and analysis of grain size}

The study site was selected based on previous studies by Jokinen et al. (2015), where it was found that the sediment in the basin comprises thick varves since the beginning of the 20th century, providing a high-resolution archive of environmental change for the corresponding period. Due to this apparent sensitivity of the basin to bottom water hypoxia, as manifested in the continuous laminations, together with the central location in the middle of the Archipelago Sea, we expected the site to be representative of the past environmental changes in the area. Importantly, despite the contrasting bottom water oxygenation between adjacent sub-basins in the area (Virtasalo et al., 2005), the long-term trends in environmental conditions are largely congruent over the entire Archipelago Sea, excluding areas close to prominent nutrient point sources (Suomela, 2011).

Two replicate sediment cores (HAV-KU-5 and HAV-KU6) were retrieved using a $5 \mathrm{~m}$ long piston corer onboard $\mathrm{R} / \mathrm{V}$ Aurelia of the Archipelago Research Institute in June 2015 (Table 1). The coring device was adjusted to start the core retrieval with the piston positioned 1-2 decimeters above the sediment-water interface, in order to capture the sediment surface as intact as possible. In the laboratory, the cores were split lengthwise and trimmed for digital photography and description of lithology. All of the following analyses, except for X-radiography, were conducted for the HAV-KU-6 core only. The sediment was sub-sampled into cubic $\left(7 \mathrm{~cm}^{3}\right)$ polystyrene sample boxes at approximately every $3.0 \mathrm{~cm}$ for geochemical analyses. In addition, the HAV-KU-6 core was continuously subsampled at $1 \mathrm{~cm}$ resolution into reclosable polyethylene bags for ${ }^{137} \mathrm{Cs},{ }^{14} \mathrm{C}$, and grain size analyses. Grain size distributions were analyzed at every $10 \mathrm{~cm}$ by a Coulter LS200 laser diffractometer after pretreatment with excess $\mathrm{H}_{2} \mathrm{O}_{2}$ and dispersing the particles in an ultrasonic bath.

\subsection{Geochronological methods}

Age constraints for the age model were obtained based on visual varve counting (1900 AD onwards), ${ }^{137} \mathrm{Cs}$ profiles, and recognizable features in the measured atmospheric lead $(\mathrm{Pb})$ fallout profile. Three analysts independently counted the varves within the continuously laminated interval $(0-76 \mathrm{~cm}$ core depth) from the freshly split sediment surface in order to constrain the reproducibility of the method. To fix this floating varve chronology, ${ }^{137} \mathrm{Cs}$ activity was measured for the topmost $60 \mathrm{~cm}$ of the core by measuring the gamma spectra of the wet subsamples at the Geological Survey of Finland using an EG\&E Ortec $\mathrm{ACE}^{\mathrm{TM}}-2 \mathrm{~K}$ spectrometer with a 4 in. (1 decimeter) NaI / Tl detector. Two or three consecutive $1 \mathrm{~cm}$ thick subsamples were combined for the 20-60 and 0-
$20 \mathrm{~cm}$ depth intervals, respectively, to gain enough material for the measurement. No corrections were applied for the results, because the target was only to detect relative ${ }^{137} \mathrm{Cs}$ activity peaks (Jokinen et al., 2015). Due to the lack of datable macrofossils, we also attempted to constrain the age model with bulk sediment radiocarbon dating of the $\mathrm{NaOH}$-soluble fraction as suggested by Rößler et al. (2011). The $\mathrm{NaOH}-$ extraction and accelerator mass spectrometry (AMS) $-{ }^{14} \mathrm{C}$ measurements for nine selected core depths were conducted at the Poznan Radiocarbon Laboratory, Poland (Goslar et al., 2004). In addition, we compared our bulk sediment $\mathrm{Pb}$ profiles with the $\mathrm{Pb}$ fallout records from varved lakes in Sweden (Brännvall et al., 1999) to constrain the chronology.

\subsection{X-radiography, trace fossils, and bioturbation index}

For $\mathrm{X}$-radiography, plastic boxes $(50 \times 4 \times 2 \mathrm{~cm})$ were pressed into the sediment, cut out using a steel string, trimmed with a thin aluminum sheet, and sealed after inserting a lid (Virtasalo et al., 2006). Due to disturbance of the uppermost sediments in the reference half of HAV-KU-6 during splitting of the core, the subsampling for X-radiography for the topmost $170 \mathrm{~cm}$ was done for the replicate core HAV-KU5. For the bottom part, the subsampling was conducted for HAV-KU-6 due to the longer core retrieval (Table 1). The cores were correlated visually based on the occurrence of the laminated intervals and the boundaries of the lithological units described below. The 2-D projections of the sedimentary structures were investigated from high-resolution digital X-radiographs of the boxes, which were obtained by a custom-made tungsten-anode micro-computed-tomography Nanotom device (Phoenix|Xray Systems+ Services GmbH) at the University of Helsinki. Power settings of the X-ray source were $100 \mathrm{kV}$ and $150 \mu \mathrm{A}$, and the detector was adjusted to exposure time of $1 \mathrm{~s}$ and an averaging of 30 images per radiograph. The resulting pixel size in the $\mathrm{X}$-radiographs was $38 \mu \mathrm{m}$. X-radiographs were used for further lithological description as well as for analysis of bioturbation index and ichnological structures to the ichnogenus level (for ichnofossil descriptions, see Virtasalo et al., 2011a) in $6 \mathrm{~cm}$ thick sediment intervals. We assigned a bioturbation index of $1-$ 4, modified from Behl and Kennett (1996), to these intervals based on the preservation of the primary sedimentary fabric so that high values denote intense mixing (Table 2).

\subsection{Geochemical analyses}

\subsubsection{Carbon and nitrogen contents and stable isotope ratios}

Lids of the polystyrene sample boxes were removed, the samples were freeze-dried, and the dry bulk density was calculated. Subsequently, the sediment samples were ground in an agate mortar and analyzed for total carbon $\left(\mathrm{C}_{\text {tot }}\right)$ and nitro- 
Table 1. Retrieved sediment cores.

\begin{tabular}{llllrrrr}
\hline Core ID & Sampling date & $\begin{array}{l}\text { Latitude } \\
\text { (WGS 84) }\end{array}$ & $\begin{array}{l}\text { Longitude } \\
\text { (WGS 84) }\end{array}$ & $\begin{array}{r}\text { Water depth } \\
(\mathrm{m})\end{array}$ & Gear & $\begin{array}{l}\text { Research } \\
\text { vessel }\end{array}$ & $\begin{array}{r}\text { Recovery } \\
(\mathrm{cm})\end{array}$ \\
\hline HAV-KU-5 & 11 June 2015 & $60^{\circ} 14.117 \mathrm{~N}$ & $22^{\circ} 02.642 \mathrm{E}$ & 23.3 & Piston corer & Aurelia & 330 \\
HAV-KU-6 & 11 June 2015 & $60^{\circ} 14.116 \mathrm{~N}$ & $22^{\circ} 02.642 \mathrm{E}$ & 23.3 & Piston corer & Aurelia & 390 \\
\hline
\end{tabular}

Table 2. Classification scheme for assessing bioturbation index, modified from Behl and Kennett (1996).

\begin{tabular}{ll}
\hline $\begin{array}{l}\text { Bioturbation } \\
\text { index }\end{array}$ & Description of the sedimentary fabric \\
\hline 1 & $\begin{array}{l}\text { Unbioturbated sediment with distinct, continuous lamination } \\
\text { Diffuse, discontinuous, or irregular laminations }\end{array}$ \\
3 & $\begin{array}{l}\text { Slightly bioturbated sediment, with either faint, diffuse laminations/bedding or with few discrete } \\
\text { patches of laminations surrounded by homogenized sediment }\end{array}$ \\
4 & Completely bioturbated sediment wherein the primary sedimentary fabric is thoroughly obliterated \\
\hline
\end{tabular}

gen $\left(\mathrm{N}_{\text {tot }}\right)$ by a CHNS analyzer (TruSpec Micro, LECO Corporation) in the Department of Food and Environmental Sciences at the University of Helsinki. The amount of inorganic $\mathrm{C}$ and $\mathrm{N}$ was assumed to be negligible in this setting, and thus $\mathrm{C}_{\text {tot }}$ and $\mathrm{N}_{\text {tot }}$ contents are assumed to equal to $\mathrm{C}_{\text {org }}$ and $\mathrm{N}_{\text {org }}$, respectively (Jilbert et al., 2018). The relative contributions of terrestrial plant-derived $\left(\% \mathrm{OC}_{\text {terr }}\right)$ and phytoplanktonderived $\mathrm{OM}\left(\% \mathrm{OC}_{\mathrm{phyt}}\right)$ to the total $\mathrm{C}_{\mathrm{org}}$ were estimated with a simple two-end-member mixing model for the molar $\mathrm{N} / \mathrm{C}$ ratio, applying end-member values of $\mathrm{N} / \mathrm{C}_{\text {terr }}=0.04$ $(\mathrm{C} / \mathrm{N}=25)$ and $\mathrm{N} / \mathrm{C}_{\text {phyt }}=0.13(\mathrm{C} / \mathrm{N}=7.7)$ for terrestrial and phytoplankton-derived OM, respectively (Goñi et al., 2003):

$\% \mathrm{OC}_{\text {terr }}=\frac{(\mathrm{N} / \mathrm{C})_{\text {sample }}-(\mathrm{N} / \mathrm{C})_{\mathrm{phyt}}}{(\mathrm{N} / \mathrm{C})_{\mathrm{terr}}-(\mathrm{N} / \mathrm{C})_{\mathrm{phyt}}} \times 100$,

where $\% \mathrm{OC}_{\text {terr }}=100-\% \mathrm{OC}_{\text {phyt }}$. The terrestrial endmember integrates various sources of terrestrial OM, from fresh vascular plant detritus to more degraded soil OM. Since virtually all of the OM transported by rivers to the coastal zone of the Archipelago Sea passes through the soil reservoir and enters the marine environment as a mixture of variably degraded material, further deconvolution of the terrestrial end-member by $\mathrm{N} / \mathrm{C}$ ratios alone is impractical. The validity of these end-member values for determining terrestrial vs. phytoplankton material, however, was recently confirmed by a study in the southern coast of Finland, where a strong gradient of $\mathrm{N} / \mathrm{C}$ values of sediment OM was reported along an estuarine transect (Jilbert et al., 2018). Further assumptions in the mixing model are that the $\mathrm{N} / \mathrm{C}$ ratios of the both end-members are temporally and spatially constant and that these values remain effectively unaltered during OM sedimentation and burial. To obtain the desired fraction of terrestrially derived $\mathrm{C}_{\text {org }}$ rather than $\mathrm{N}_{\text {org }}$ from this model, we use $\mathrm{N} / \mathrm{C}$ instead of the $\mathrm{C} / \mathrm{N}$ ratio for the calculation
(Perdue and Koprivnjak, 2007). Elsewhere in the text and in the figures we refer to the more commonly used $\mathrm{C} / \mathrm{N}$ ratio.

In the Laboratory of Chronology at the University of Helsinki, selected freeze-dried and ground samples were measured for stable isotope compositions of carbon $\left(\delta^{13} \mathrm{C}_{\text {org }}\right)$ and nitrogen $\left(\delta^{15} \mathrm{~N}\right)$ by an isotope ratio mass spectrometer (Delta V Plus, Thermo Fisher Scientific) coupled to an NC2500 elemental analyzer. The measured $\delta^{13} \mathrm{C}_{\text {org }}$ and $\delta^{15} \mathrm{~N}$ values are reported relative to the Vienna Pee Dee Belemnite (V-PDB) and AIR scales for C and N, respectively. Precision of the measurements, as checked against in-house and reference standards, yielded $<0.02 \%(1 \sigma)$ for both elements. Based on analysis of replicate samples, precision of the entire procedure was $<0.2$ and $<2.6 \%$ for $\delta^{13} \mathrm{C}_{\text {org }}$ and $\delta^{15} \mathrm{~N}$, respectively. To account for the historic decline in $\delta^{13} \mathrm{C}$ of atmospheric $\mathrm{CO}_{2}$ due to fossil fuel burning and deforestation, the measured values for samples postdating $1700 \mathrm{AD}$ were corrected according to the equation suggested by Verburg (2007):

$$
\begin{aligned}
\% \mathrm{OC}_{\text {terr }} \delta^{13} \mathrm{C} & =7.7738118 \times 10^{-16} \times Y^{6} \\
& -1.2222044 \times 10^{-11} \times Y^{5} \\
& +7.1612441 \times 10^{-8} \times Y^{4} \\
& -2.1017147 \times 10^{-4} \times Y^{3} \\
& +3.3316112 \times 10^{-1} \times Y^{2} \\
& -273.715025 \times Y+91703.261,
\end{aligned}
$$

where $Y=$ year (AD) of the sediment accumulation.

\subsubsection{Biomarker analyses}

Selected freeze-dried and homogenized samples were analyzed for various biomarkers at the Department of Marine Geology in the Leibniz Institute for Baltic Sea Research (IOW) following Kaiser and Arz (2016). Briefly, 0.5-1.0 g of 
sediment was used for accelerated solvent extraction (Dionex ASE 350, Thermo Fisher Scientific) with a 9:1 volumetric mixture of dichloromethane and methanol using high pressure $(100 \mathrm{bar})$ and temperature $\left(100^{\circ} \mathrm{C}\right)$. After the addition of internal standards (squalane, nonadecan-2-one, $5 \alpha$ androstan- $3 \beta$-ol, and $\mathrm{C}_{46}$-GDGT) for quantification, the total extracts were divided into four fractions by microscale silica gel column chromatography. For the determination of $\mathrm{Pr}$ and $\mathrm{Ph}$ contents, the apolar alkane fraction was measured on a multichannel Trace Ultra gas chromatograph (Thermo Fisher Scientific), utilizing a split/splitless inlet, a DB-5 MS capillary column, and a FID (flame ionization detector) detector. Peak identification from the obtained chromatograms was done based on the comparison of peak retention times with an external standard containing $\mathrm{Pr}, \mathrm{Ph}$, and $n-\mathrm{C}_{8}$ to $n$ $\mathrm{C}_{40}$ alkanes, complemented with GC-MS analyses (see for details Kaiser and Arz, 2016). To calculate the BIT index, the most polar fraction (including glycerol dialkyl glycerol tetraethers, GDGTs) was measured with HPLC APCI-MS (Dionex Ultimate 3000 UHPLC, Thermo Fisher Scientific system coupled to a MSQ Plus, Thermo Fisher Scientific) (see for details Kaiser and Arz, 2016).

\subsubsection{Major and trace element contents}

Elemental contents of the freeze-dried and homogenized samples were estimated by a combination of ICP-OES (inductively coupled plasma optical emission spectrometry) and ICP-MS (inductively coupled plasma mass spectrometry) analysis. Initial ICP-OES analysis for $\mathrm{K}$ and $\mathrm{Ti}$ was performed at the Department of Food and Environmental Sciences at the University of Helsinki. A portion of $0.1-0.2 \mathrm{~g}$ of dry sediment was dissolved in $2.5 \mathrm{~mL}$ of $\mathrm{HF}(38 \%)$ and $2.5 \mathrm{~mL}$ of a mixture of $\mathrm{HClO}_{4}(70 \%)$ and $\mathrm{HNO}_{3}(65 \%)$ (volumetric ratio $3: 2$ ) in closed Teflon bombs at $90^{\circ} \mathrm{C}$ for $12 \mathrm{~h}$. After evaporating the acids at $160^{\circ} \mathrm{C}$, the remaining gel was dissolved in Suprapur ${ }^{\circledR} 1 \mathrm{M} \mathrm{HNO}_{3}$ and analyzed for $\mathrm{K}$ and $\mathrm{Ti}$ by ICP-OES (Thermo Fisher Scientific, precision determined by replicate analyses $<5 \%$ ).

Accuracy of the initial ICP-OES results was checked by digestion and analysis of a subset of 28 samples at IOW together with the international reference material SGR-1b (USGS). A total of $50 \mathrm{mg}$ of dried and ground sediment was first treated in open Teflon vessels (PDS-6; Heinrichs et al., 1986) with $1 \mathrm{~mL} \mathrm{HNO}_{3}(65 \%)$ at $60^{\circ} \mathrm{C}$ for $1 \mathrm{~h}$ to oxidize OM. After addition of $2 \mathrm{~mL}$ concentrated $\mathrm{HF}$ and $2 \mathrm{~mL}$ concentrated $\mathrm{HClO}_{4}$, the closed vessels were heated at $180^{\circ} \mathrm{C}$ for $12 \mathrm{~h}$. After evaporation of the acids on a hot plate at $180^{\circ} \mathrm{C}$, the digestions were fumed off 3 times with $6 \mathrm{M} \mathrm{HCl}$, re-dissolved in $25 \mathrm{ml} 2 \mathrm{vol} \% \mathrm{HNO}_{3}$, and finally measured by ICP-OES (iCAP 7300 Duo, Thermo Fisher Scientific) for K and Ti using Sc as internal standard. Precision and accuracy of the measurements of SGR-1b at IOW were respectively 0.7 and $-5.9 \%$ for $\mathrm{K}$ and 0.8 and $-7 \%$ for Ti. Constant offsets of up to $20 \%$ were observed between the datasets from
Helsinki and IOW for the 28 samples. A correction factor was thus applied to the results from the Helsinki data using a linear regression between the IOW and Helsinki results. The $\mathrm{K}$ and $\mathrm{Ti}$ data reported in this paper are thus the corrected Helsinki data and may be considered to have precision and accuracy $<10 \%$ (this value integrates both the quality of the IOW measurements and the goodness of fit of the linear regression). Internal reproducibility between the two sample sets was good $(<7 \%)$, suggesting that the offsets observed between the respective ICP-OES datasets from Helsinki and IOW were related to analytical issues rather than the digestion protocols.

ICP-MS was used to determine the contents of $\mathrm{Mo}, \mathrm{Pb}$, and the ratio of stable $\mathrm{Pb}$ isotopes $\left({ }^{206} \mathrm{~Pb} /{ }^{207} \mathrm{~Pb}\right)$. ICP-MS analysis (iCAP Q, Thermo Fisher Scientific) was performed at IOW on the complete set of digests from Helsinki and the subset of 28 digested samples from IOW. The international reference material SGR-1b (USGS) served to determine the precision and accuracy of Mo $(0.7 /-1.6 \%)$ and $\mathrm{Pb}(0.6 /-2.2 \%)$ measurements using $\mathrm{Rh}$ and $\mathrm{Ir}$ as internal standards in KED (kinetic energy discrimination) mode using $\mathrm{He}$ as collision gas. For determination of ${ }^{206} \mathrm{~Pb} /{ }^{207} \mathrm{~Pb}$ in standard mode, the samples were diluted to a $\mathrm{Pb}$ concentration of $\sim 1 \mu \mathrm{g} \mathrm{L}^{-1}$ and the instrument was tuned to provide best results for the NIST standard SRM-981, resulting in a precision $<0.07 \%$.

All measured elemental contents were corrected for the weight of the salt in the pore water using the ambient salinity and porosity (Lenz et al., 2015). Mass accumulation rates (MARs) of the individual elements were calculated as follows:

$\mathrm{MAR}_{x}=\frac{\mathrm{C}_{x}}{100} \times \mathrm{LSR} \times \mathrm{DBD}$,

where $\mathrm{C}_{x}$ is the element content $(\%)$, LSR is the linear sedimentation rate $\left(\mathrm{cm} \mathrm{a}^{-1}\right), \mathrm{DBD}$ is the dry bulk density $\left(\mathrm{g} \mathrm{cm}^{-3}\right)$, and subscript $x$ denotes the element in question.

\section{Results}

\subsection{Age model}

The three independent varve counts for the continuously laminated recent sediments $(3-76 \mathrm{~cm})$ suggest that this section covers $113 \pm 5$ varve years of deposition. The ${ }^{137} \mathrm{Cs}$ activity increase at $33 \mathrm{~cm}$ core depth, derived from the Chernobyl nuclear power plant accident in $1986 \mathrm{AD}$, enabled us to fix the floating varve chronology, which indicated that the onset of continuous lamination occurred at $\sim 1900$ AD (Fig. 2). A similar ${ }^{137} \mathrm{Cs}$ activity increase at this site was found at $32 \mathrm{~cm}$ core depth in a core taken in 2013 AD (Jokinen et al., 2015), implying that no marked loss of surface sediment occurred during the piston coring. This is supported by the varve counting, which (after fixing with the ${ }^{137} \mathrm{Cs}$ activity 
profile) suggested that the sediment surface was indeed of modern age (Table 3 ).

The apparent temporal fluctuations in the magnitude of the bulk sediment reservoir age as indicated by the downcore reversals in ${ }^{14} \mathrm{C}$ age (Fig. 2; Lougheed et al., 2017) impeded utilization of the bulk sediment AMS- ${ }^{14} \mathrm{C}$ dates for the construction of the age model. Because our data did not enable robust correction for such variations, we desisted from using bulk sediment ${ }^{14} \mathrm{C}$ dates as age constraints.

To estimate the content of atmospheric pollution $\mathrm{Pb}$ in the sediment, we applied a simple two-component mixing model following Brännvall et al. (1999):

$\mathrm{Pb}_{\text {pollution }}=$

$\frac{\left({ }^{206} \mathrm{~Pb} /{ }^{207} \mathrm{~Pb}\right)_{\text {sample }}-\left({ }^{206} \mathrm{~Pb} /{ }^{207} \mathrm{~Pb}\right)_{\text {background }}}{\left({ }^{206} \mathrm{~Pb} /{ }^{207} \mathrm{~Pb}\right)_{\text {pollution }}-\left({ }^{206} \mathrm{~Pb} /{ }^{207} \mathrm{~Pb}\right)_{\text {background }}} \times \mathrm{Pb}_{\text {sample }}$.

The background isotope composition of $\mathrm{Pb}$ was calculated as the mean prior to the apparent onset of $\mathrm{Pb}$ pollution at $900 \mathrm{AD}$ (Fig. 2), which yielded an estimate of 1.397. We used the age model based on ${ }^{137} \mathrm{Cs}$ dating and varve counting for the sediments deposited after $1900 \mathrm{AD}$ to assign a time-dependent ${ }^{206} \mathrm{~Pb} /{ }^{207} \mathrm{~Pb}$ composition for the pollution $\mathrm{Pb}$. We assumed a constant ${ }^{206} \mathrm{~Pb} /{ }^{207} \mathrm{~Pb}$ ratio of 1.17 for the pollution $\mathrm{Pb}$ prior to $1900 \mathrm{AD}$, a linear decrease from 1.17 to 1.15 between 1900 and $1945 \mathrm{AD}$, and a constant ratio of 1.15 since 1945 AD (Brännvall et al., 1999, and references therein).

We found a remarkable consistency between our $\mathrm{Pb}$ record and the pollution $\mathrm{Pb}$ profiles of varved lakes in eastern Sweden, where the preindustrial $\mathrm{Pb}$ fallout was mainly sourced from mainland Europe and from the British Isles (Brännvall et al., 1999; Fig. 2). Hence, we used the main $\mathrm{Pb}$ pollution features found consistently in all of these lakes to constrain an age model for our sediment core (Fig. 2; Table 3). The onset of medieval $\mathrm{Pb}$ pollution (at $900 \mathrm{AD}$, Lougheed et al., 2012) and the medieval pollution maximum (at $1200 \mathrm{AD}$, Lougheed et al., 2012, 2017; Zillén et al., 2012) have previously been used as age constraints in sediments from the Baltic Proper. However, our study is, to our best knowledge, the first to identify the $1530 \mathrm{AD}$ pollution peak and the pollution minima of 1350 and 1600 AD (Brännvall et al., 1999; Renberg et al., 2002) as age-depth points in Baltic Sea sediments.

A conservative $1 \sigma$ uncertainty of 50 years for all of the $\mathrm{Pb}$ constraints was assumed. In addition to this, we assigned an additional uncertainty for the $\mathrm{Pb}$ age constraints in cases where the position of the feature was ambiguous by first calculating the mean LSR for the 900-1900 AD period (from the sharp onset of $\mathrm{Pb}$ pollution to the onset of continuous lamination). Based on this LSR estimate $\left(0.21 \mathrm{~cm} \mathrm{a}^{-1}\right)$ and the width of the $\mathrm{Pb}$ features, an additional uncertainty was added to these constraints by assuming that the width of each recognized feature in our $\mathrm{Pb}$ profile corresponds to the $2 \sigma$ uncertainty in the correlation with the Swedish pollution $\mathrm{Pb}$ records.

The obtained age constraints (Table 3 ) were used to construct a Bayesian age model in OxCal 4.2 software (Bronk Ramsey, 2009), using the $P$-sequence function (Bronk Ramsey, 2008) with a $k$ value of 20 . The resulting age model indicates that the core HAV-KU-6 covers $\sim 1500$ years of depositional history in the area (Fig. 2). A substantial increase in LSR is observed coincident with the onset of laminated sediment accumulation at $76 \mathrm{~cm}$ depth (Fig. 2).

\subsection{Lithology and trace fossils}

The sediment in the core HAV-KU-6 is characterized by organic-rich mud, which conforms to the brackish-water mud drift sensu Virtasalo et al. (2007), indicative of recent deposition in the basin. Based on lithology, the core can be divided into four units as described below (Figs. 2 and 3). These units approximately correspond to the pre-MCA, MCA, LIA, and MoWP intervals (Fig. 3).

The basal part (393-324 cm, 500-780 AD) of the core HAV-KU-6 roughly corresponds to the pre-MCA interval and comprises seemingly homogenous greenish-brown mud. The $\mathrm{X}$-radiographs show that this mud is intensely burrow mottled (Planolites mottling) and is thus characterized by a bioturbation index of 4 (Fig. 4), although discrete trace fossils are hardly discernible due to the high burrow density and low contrast enhancement by pyritization along the burrows (Fig. 3a), probably resulting in substantial underestimation of the number of traces. The upper contact to the thinly bedded mud is relatively sharp, but no clear signs of erosion are observed in the X-radiograph.

The thinly bedded mud $(324-201 \mathrm{~cm}, \sim 780-1290$ AD) roughly corresponds to the MCA interval and comprises $2-5 \mathrm{~cm}$ thick beds, which are burrow mottled and poorly graded, and locally inverse graded (Fig. 3b). The bioturbation index in this unit varies from 3 to 4 depending on the preservation of the beds (Fig. 4). In places where the bedding pattern is clearly visible, the basal parts of the beds are dark grey and appear dark in the X-radiographs, suggesting relatively low density. In contrast, the upper parts of the beds are greenish-grey and appear bright in the X-radiographs, pointing to higher density and coarser grain size. The beds are mottled by abundant Planolites, rare to abundant Arenicolites, and rare large Planolites ichnofossils and complex bivalve biodeformational structures (Figs. $3 b$ and 4 ).

The thinly bedded mud is gradationally overlain by greenish-grey mud roughly corresponding to the LIA interval (201-76 cm, $\sim 1290-1900$ AD), with occasional $1-4 \mathrm{~cm}$ thick indistinctly laminated intervals. In general, this unit is characterized by a complete obliteration of the primary sedimentary fabric (bioturbation index of 4) and the trace fossil assemblage comprises abundant Planolites and Arenicolites, rare large Planolites, and complex bivalve biodeformational structures (Figs. 3c and 4). The bioturbation index 


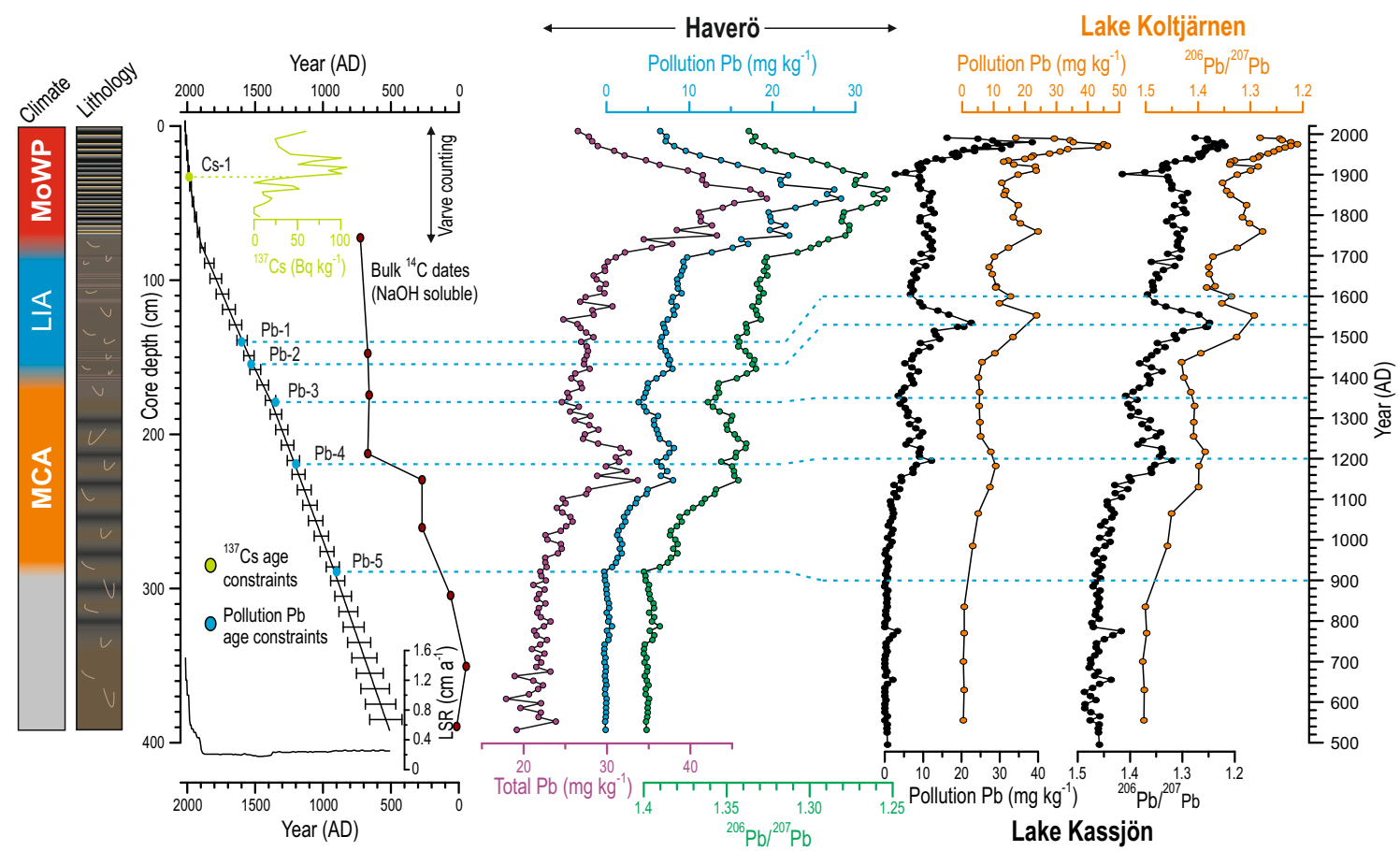

Figure 2. Simplified lithology, constructed age model, and ${ }^{137} \mathrm{Cs}$ and $\mathrm{Pb}$ profiles for the sediment core HAV-KU-6. Correlation of Pb profiles with pollution $\mathrm{Pb}$ reconstructions from two varved lakes in Sweden (data from Brännvall et al., 1999) are also shown. For details of the indicated age constraints the reader is referred to Table $2 . \mathrm{NaOH}$-extractable bulk sediment ${ }^{14} \mathrm{C}$ dates are also indicated, although they were not used for constructing the age model due to the apparent temporal variation in the bulk sediment reservoir age. Note the reversed $x$ axes for the ${ }^{206} \mathrm{~Pb} /{ }^{207} \mathrm{~Pb}$ profiles. The error bars for the age model indicate $1 \sigma$ uncertainty range. The linear sedimentation rate (LSR) profile calculated based on the age model is also shown.

and the number of traces decline rapidly at $91 \mathrm{~cm}$ core depth $(\sim 1820 \mathrm{AD})$ and remain low to the top of the unit (Fig. 4). The upper contact to the sharply laminated mud is gradational.

The sharply laminated mud $(76-0 \mathrm{~cm})$ roughly corresponds to the MoWP and comprises rhythmically alternating light brown, black, and grey laminae. The thickness of the individual lamina successions varies from 2 to $13 \mathrm{~mm}$, with a generally upward increasing trend, which partly results from decreasing compaction. These laminites correspond to the varves described by Jokinen et al. (2015). Trace fossils are virtually absent in this unit (bioturbation index of 1-2), although occasional blurring of the laminations is observed (Figs. 3d and 4). Black sulfide staining becomes predominant from $53 \mathrm{~cm}$ upwards.

\subsection{Geochemistry}

\subsubsection{Lithogenic components: trends over the entire study interval}

Median grain size (range 1.8-2.4 $\mu \mathrm{m}$ ) and $\mathrm{Ti} / \mathrm{K}$ (range $0.146-0.159)$ are closely coupled and show a generally decreasing trend towards the present (Fig. 4). Superimposed on this trend the LIA stands out as an interval of de- creased values in both profiles (median grain size $\sim 1.9 \mu \mathrm{m}$, $\mathrm{Ti} / \mathrm{K} \sim 0.149)$ in comparison to the pre-MCA, MCA, and MoWP.

\subsubsection{Organic component: trends over the entire study interval}

The proxies for organic matter contents and composition correlate strongly with each other and show profiles very similar to those in $\mathrm{Ti} / \mathrm{K}$ and grain size (e.g., $\mathrm{Ti} / \mathrm{K}$ vs. $\mathrm{C}_{\text {org }}$ $r_{\mathrm{s}}=0.83, p<0.001$; Table 4). Namely, the organic proxies display a long-term trend (towards lower $\mathrm{C}_{\text {org }}$ content and $\delta^{13} \mathrm{C}_{\text {org }}$, higher BIT and $\mathrm{C} / \mathrm{N}$ ) onto which changes during the MCA and MoWP (towards higher $\mathrm{C}_{\text {org }}$ content and $\delta^{13} \mathrm{C}_{\text {org }}$, lower BIT and $\mathrm{C} / \mathrm{N}$ ) are superimposed (Fig. 5). Despite the relatively narrow ranges of values for $\mathrm{C}_{\text {org }}$ (2.9$4.5 \%), \mathrm{C} / \mathrm{N}(8.6-9.9)$, BIT index $(0.18-0.29)$, and $\delta^{13} \mathrm{C}_{\text {org }}$ $(-23.9$ to $-22.2 \%$ ) , variability in these proxies is internally consistent over the last 1500 years (Fig. 5). The MAR of $\mathrm{C}_{\text {org }}$ remained between 20 and $50 \mathrm{~g} \mathrm{~m}^{-2} \mathrm{a}^{-1}$ until the onset of the 20th century, after which it increased up to $\sim 100 \mathrm{~g} \mathrm{~m}^{-2} \mathrm{a}^{-1}$ by the end of the century. Meanwhile, the bulk sedimentary $\delta^{15} \mathrm{~N}$ remained fairly constant $(3.1-3.5 \%$ ) throughout much of the study period, until a steady increase from 3.4 to $5.2 \%$ o in the 1900s. 
Table 3. Age constraints given as an input for the age model constructed using OxCal 4.2 software. Pb pollution features were obtained from Brännvall et al. (1999). The IDs are as in Fig. 2. Measured bulk sediment AMS- ${ }^{14} \mathrm{C}$ dates are given as ${ }^{14} \mathrm{C}$ ages without any calibration or reservoir effect correction, although they were not used in the age model due to the large uncertainties in the bulk sediment reservoir effect.

\begin{tabular}{|c|c|c|c|c|c|}
\hline $\begin{array}{l}\text { Dating } \\
\text { method }\end{array}$ & Event & ID & $\begin{array}{r}\text { Core depth } \\
(\mathrm{cm})\end{array}$ & $\begin{array}{r}\text { Age } \\
\text { (year AD) }\end{array}$ & $\begin{array}{l}\text { Age uncertainty } \\
( \pm 1 \sigma)\end{array}$ \\
\hline Varves & & & 3 & 2014 & 5 \\
\hline Varves & & & 13 & 2006 & 5 \\
\hline Varves & & & 23 & 1997 & 5 \\
\hline Cs-137 & Chernobyl & Cs-1 & 33 & 1986 & 2 \\
\hline Varves & & & 43 & 1970 & 5 \\
\hline Varves & & & 53 & 1951 & 5 \\
\hline Varves & & & 63 & 1931 & 5 \\
\hline Varves & & & 73 & 1908 & 5 \\
\hline Varves & & & 76 & 1901 & 5 \\
\hline $\mathrm{Pb}$ pollution & Pollution minimum & $\mathrm{Pb}-1$ & 140 & 1600 & 56 \\
\hline $\mathrm{Pb}$ pollution & Pollution maximum & $\mathrm{Pb}-2$ & 155 & 1530 & 56 \\
\hline $\mathrm{Pb}$ pollution & Pollution minimum & $\mathrm{Pb}-3$ & 179 & 1350 & 50 \\
\hline $\mathrm{Pb}$ pollution & Medieval pollution peak & $\mathrm{Pb}-4$ & 219 & 1200 & 71 \\
\hline $\mathrm{Pb}$ pollution & Onset of medieval pollution & $\mathrm{Pb}-5$ & 289 & 900 & 50 \\
\hline \multicolumn{6}{|c|}{ AMS- ${ }^{14} \mathrm{C}$ dates } \\
\hline Radiocarbon & & Poz-76784 & 72.5 & 725 & 30 \\
\hline Radiocarbon & & Poz-76785 & 147.5 & 670 & 30 \\
\hline Radiocarbon & & Poz-81729 & 174.5 & 660 & 30 \\
\hline Radiocarbon & & Poz-81730 & 212.5 & 670 & 30 \\
\hline Radiocarbon & & Poz-79786 & 229.5 & 270 & 30 \\
\hline Radiocarbon & & Poz-81731 & 260.5 & 270 & 30 \\
\hline Radiocarbon & & Poz-76787 & 304.5 & 60 & 30 \\
\hline Radiocarbon & & Poz-81732 & 350.5 & -15 & 30 \\
\hline Radiocarbon & & Poz-76788 & 389.5 & 15 & 30 \\
\hline
\end{tabular}

\subsubsection{Proxies for hypoxia: trends over the entire study interval}

Sedimentary Mo content and MAR (ranges $2-8 \mathrm{mg} \mathrm{kg}^{-1}$ and $0.09-1.21 \mu \mathrm{g} \mathrm{cm}^{-2} \mathrm{a}^{-1}$ ) display negligible changes throughout the pre-MCA, MCA, and LIA intervals, but increase to maximum values during the MoWP (Fig. 4). When expressed as MAR, the recent increase in Mo continues to the present day (Fig. 6). The correlation between Mo and $\mathrm{C}_{\text {org }}$ is generally weak $\left(r_{\mathrm{s}}=0.18, p=0.04\right)$, although this improves towards the present (i.e., when considering the LIA and MoWP intervals only, Fig. S1 in the Supplement).

$\mathrm{Pr} / \mathrm{Ph}$ ratio also shows little systematic change throughout most of the record, recording values in the range of 0.41.0 from the pre-MCA to the early MoWP. Coincident with the subrecent increase in $\mathrm{Mo}, \mathrm{Pr} / \mathrm{Ph}$ drops sharply to nearly zero at the depth interval corresponding to $1960 \mathrm{AD}$, before recovering to 0.6 in the most recent sediments (Fig. 4). Throughout the entire record, Mo and $\mathrm{Pr} / \mathrm{Ph}$ show a negative correlation $\left(r_{\mathrm{s}}=-0.48, p<0.001 ;\right.$ Fig. S1; Table 4).

\subsubsection{Trends during the Modern Warm Period}

The recent changes observed in our proxies during the MoWP are complex and are described here in more detail. The LIA-MoWP transition (1800-1900 AD) was characterized by low Mo and $\mathrm{C}_{\text {org }}$ contents and MARs (range during the MoWP $0.17-1.21 \mu \mathrm{g} \mathrm{cm}^{-2} \mathrm{a}^{-1}$ and $22-122 \mathrm{~g} \mathrm{~m}^{-2} \mathrm{a}^{-1}$, respectively) as well as low sediment MAR (range during the MoWP 0.7-2.9 $\mathrm{kg} \mathrm{m}^{-2} \mathrm{a}^{-1}$ ) and high $\mathrm{Pr} / \mathrm{Ph}$ (Fig. 6). At $1900 \mathrm{AD}$, coinciding with the onset of continuous laminations, MARs of Mo, $\mathrm{C}_{\mathrm{org}}$, and sediment increased contemporaneously with a marked decrease in $\mathrm{Pr} / \mathrm{Ph}$. After this point, the strongly enhanced sediment MAR appears to partially dilute the Mo content, particularly in the late 20th century (see also Fig. 4). Hence we focus on the MAR of Mo as a proxy for recent changes in hypoxia during the MoWP. The Mo MAR shows a steady increase throughout the MoWP, displaying several decadal-scale oscillations (Fig. 6).

Despite declining rapidly after the onset of continuous laminations, $\mathrm{Pr} / \mathrm{Ph}$ recovered to pre-MoWP values in the period $1990 \mathrm{AD}$-present (Fig. 6). The possible reasons for this observation are discussed below. Meanwhile, the proxies for organic matter composition during the MoWP are con- 
(a)

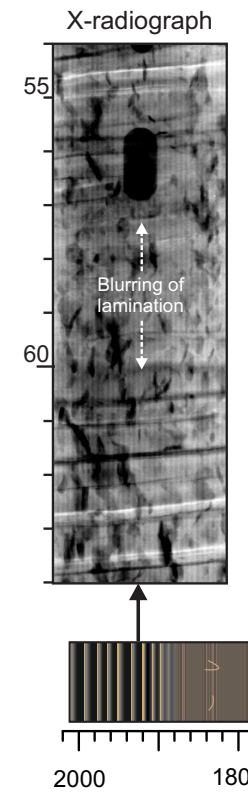

(b)

X-radiograph Interpretation

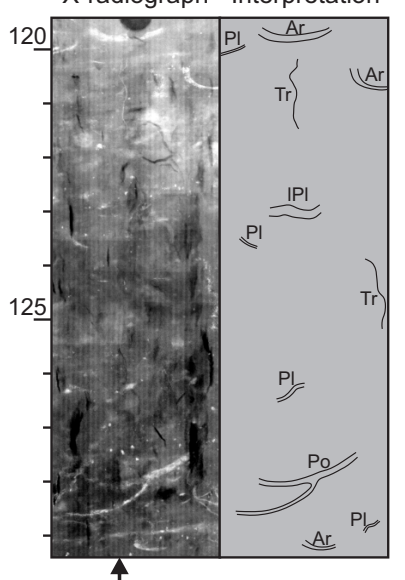

(c)

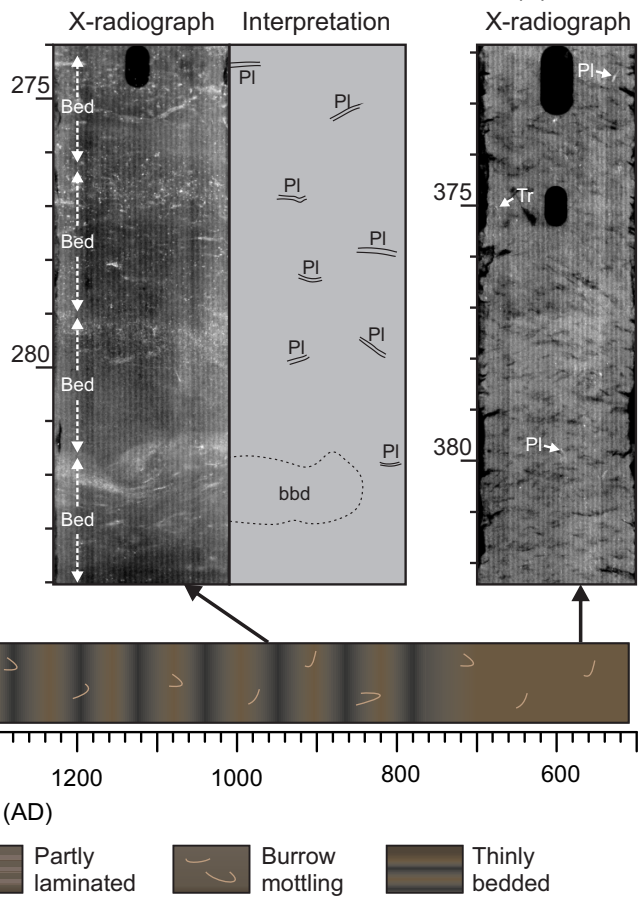

MOWP LIA MCA

Figure 3. X-radiographs of different lithological units together with their interpretations. (a) Intensely Planolites-mottled sedimentary fabric characterized by a low number of distinct traces. (b) Thinly bedded sedimentary fabric overprinted by abundant Planolites trace fossils. The lowermost bed is disturbed by bivalve biodeformation (bbd). (c) Intensely burrow-mottled sedimentary fabric with abundant Planolites (PI) and Arenicolites (Ar) trace fossils. (d) Sharply laminated sedimentary fabric punctuated with gentle blurring of the lamination. The black holes in the X-radiographs are artefacts produced by holes in the sample boxes.

Table 4. Spearman rank correlation $\left(r_{\mathrm{S}}\right)$ matrix for selected variables. The number of stars denotes the degree of significance for each pair of variables: *** for very high significance $(p<0.001)$, ** for high significance $(0.001<p<0.01), *$ for significance $(0.01<p<0.05)$, and no symbol for weak or no significance $(p<0.05)$. Correlation coefficients with absolute values exceeding 0.70 are bolded.

\begin{tabular}{lrrrrrrrrrr}
\hline & $\mathrm{C}_{\text {org }}$ & $\mathrm{C} / \mathrm{N}$ & $\mathrm{C}_{\text {org }} \mathrm{MAR}$ & $\mathrm{BIT}$ & $\mathrm{Mo}$ & $\mathrm{Mo} \mathrm{MAR}$ & $\mathrm{Pr} / \mathrm{Ph}$ & $\mathrm{Ti} / \mathrm{K}$ & $\delta^{13} \mathrm{C}_{\mathrm{org}}$ & $\delta^{15} \mathrm{~N}$ \\
\hline $\mathrm{C}_{\text {org }}$ & 1 & $* * *$ & $* * *$ & $* * *$ & $*$ & $* * *$ & - & $* * *$ & $* *$ & - \\
$\mathrm{C} / \mathrm{N}$ & $-\mathbf{0 . 7 3}$ & 1 & $* * *$ & $* * *$ & $* *$ & - & $* * *$ & $* * *$ & $* *$ & - \\
$\mathrm{C}_{\text {org }} \mathrm{MAR}$ & $\mathbf{0 . 7 0}$ & -0.34 & 1 & $* *$ & $* * *$ & $* * *$ & $*$ & $* * *$ & - & $* *$ \\
$\mathrm{BIT}$ & $\mathbf{0 . 7 4}$ & $\mathbf{0 . 7 6}$ & -0.38 & 1 & - & - & $* * *$ & $* * *$ & $* * *$ & - \\
$\mathrm{Mo}$ & 0.18 & 0.23 & 0.54 & 0.07 & 1 & $* * *$ & $* * *$ & $*$ & - & - \\
$\mathrm{Mo} \mathrm{MAR}$ & 0.37 & 0.04 & $\mathbf{0 . 8 0}$ & -0.03 & $\mathbf{0 . 9 1}$ & 1 & $* * *$ & $* * *$ & - & $* *$ \\
$\mathrm{Pr} / \mathrm{Ph}$ & 0.20 & -0.52 & -0.30 & -0.41 & -0.48 & -0.47 & 1 & - & $*$ & $*$ \\
$\mathrm{Ti} / \mathrm{K}$ & $\mathbf{0 . 8 3}$ & -0.53 & $\mathbf{0 . 8 0}$ & -0.68 & 0.40 & 0.58 & 0.05 & 1 & $* * *$ & - \\
$\delta^{13} \mathrm{C}_{\text {org }}$ & 0.51 & -0.52 & 0.09 & $-\mathbf{0 . 7 6}$ & -0.12 & -0.14 & 0.43 & 0.63 & 1 & $* *$ \\
$\delta^{15} \mathrm{~N}$ & 0.12 & 0.12 & 0.46 & 0.22 & 0.34 & 0.47 & -0.44 & 0.04 & -0.54 & 1 \\
\hline
\end{tabular}

sistent with a steady increase in the relative supply of autochthonous material. The $\delta^{13} \mathrm{C}_{\text {org }}$ values increase progressively from $1900 \mathrm{AD}$ to present $(-23.6$ to $-22.2 \%$ ), while $\mathrm{C} / \mathrm{N}$ declines from 9.8 to 9.1 .

\section{Discussion}

\subsection{Physical changes in the depositional conditions}

Although the Haverö basin has been an enclosed basin throughout the study period (Fig. 1b), the glacio-isostatic re- 


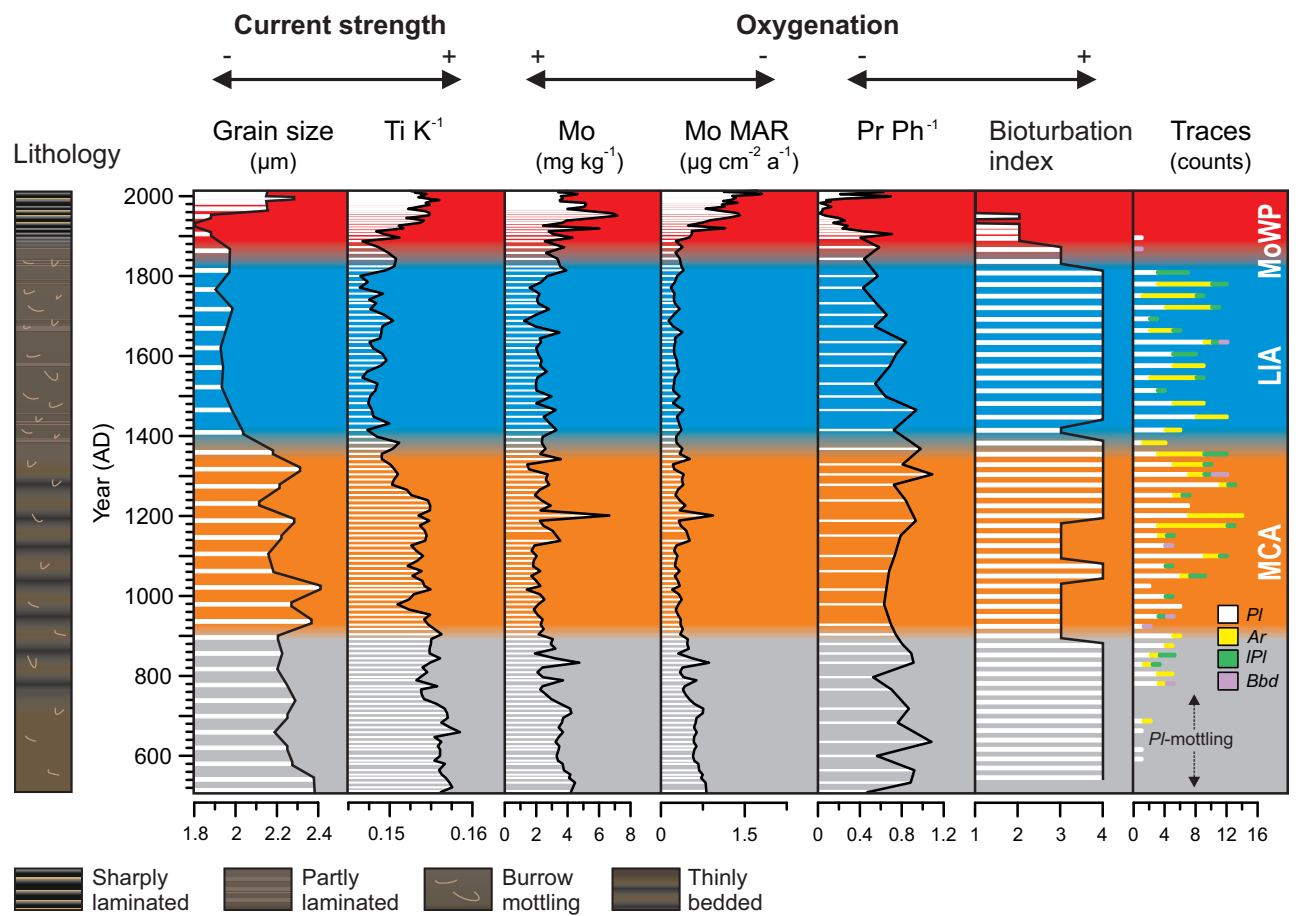

Figure 4. Profiles of median grain size and $\mathrm{Ti}$ / K denoting fluctuations in local hydrodynamic conditions plotted together with the proxies for hypoxia intensity.

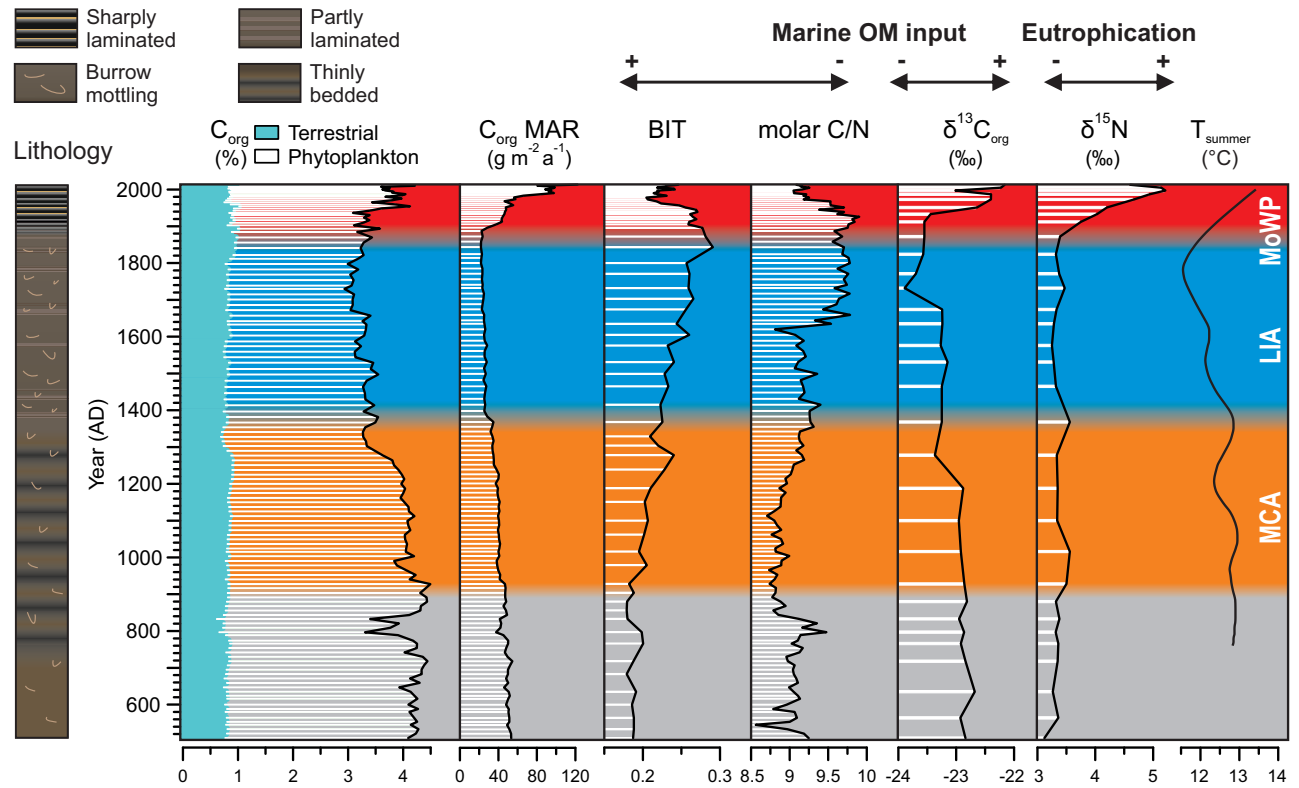

Figure 5. Geochemical profiles reflecting the delivery and preservation of organic material in the basin. Fractions of $\mathrm{C}_{\text {org }}$ were calculated from molar $\mathrm{C} / \mathrm{N}$ ratios, applying end-member values of 25 and 7.7 for terrestrial and phytoplankton-derived $\mathrm{C}_{\text {org }}$, respectively. A loesssmoothed dendroclimatic summer temperature reconstruction for southeastern Finland (data from Helama et al., 2014) is also shown. Note the marked decline in the input of phytoplankton-derived $\mathrm{C}_{\text {org }}$ during the LIA.

bound has resulted in progressively calmer depositional conditions in the area, as evidenced by the generally decreasing trajectories in $\mathrm{Ti} / \mathrm{K}$ and grain size over the past 1500 years
(Fig. 4). Assuming a constant glacio-isostatic uplift rate of $4 \mathrm{~mm} \mathrm{a}^{-1}$ for the past 1000 years (Mäkinen and Saaranen, 1998 ), and taking into account the $\sim 3 \mathrm{~m}$ of sediment ac- 

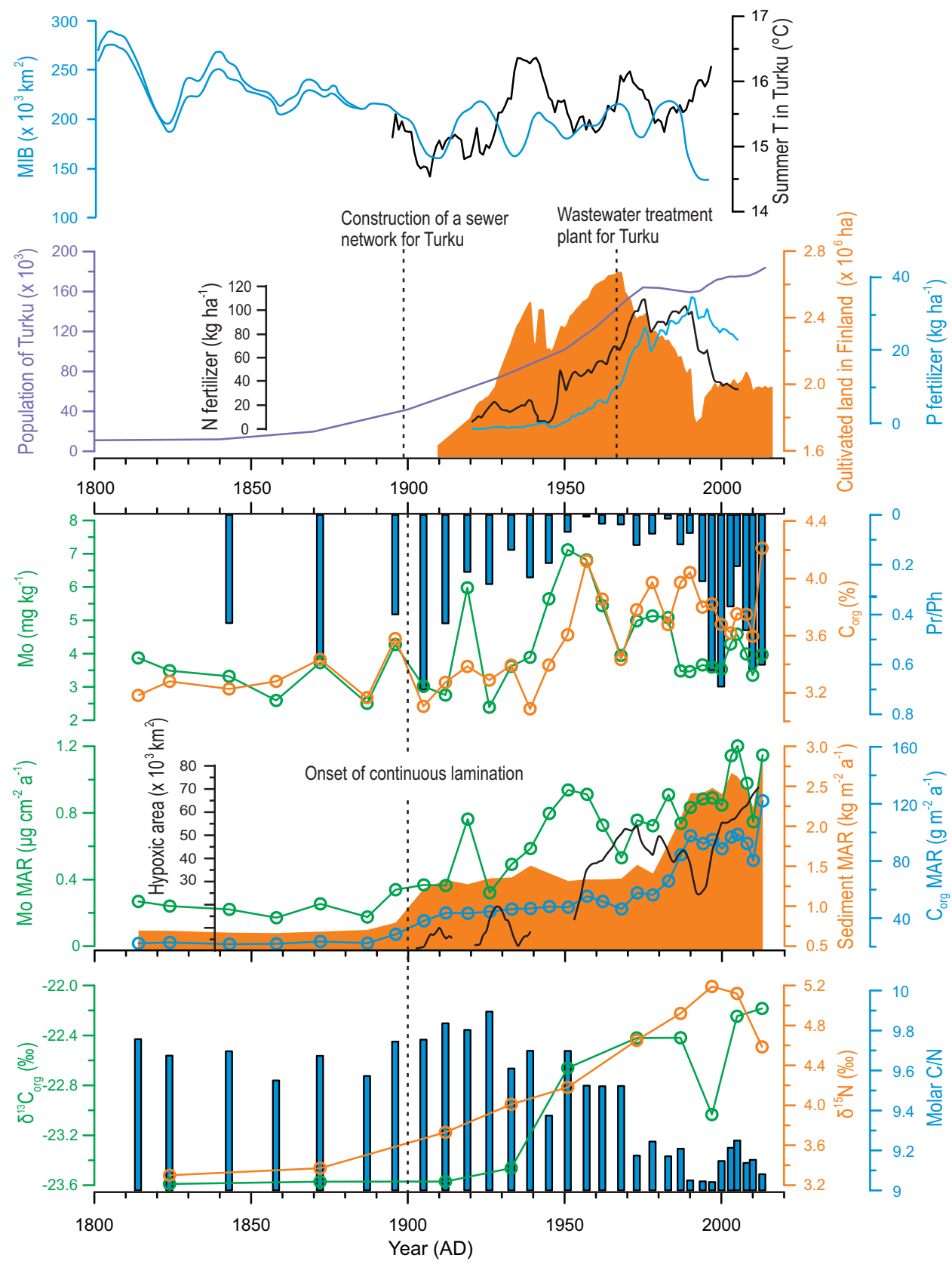

Figure 6. Comparison of possible climatic and anthropogenic drivers of eutrophication in the study area versus geochemical profiles reflecting the sources and delivery of organic matter to the sediment $\left(\mathrm{C}_{\mathrm{org}}, \delta^{13} \mathrm{C}_{\mathrm{org}}\right.$, and $\left.\delta^{15} \mathrm{~N}\right)$ and redox conditions at the sediment-water interface (content and MAR of Mo, Pr / Ph ratio) over the past $\sim 200$ years. Modeled development of hypoxic area in the Baltic Sea (redrawn from Carstensen et al., 2014b), excluding Kattegat, Danish straits, and the coastal zone, is shown for reference. Data regarding agricultural practices in Finland (annual sales of $\mathrm{N}$ and P fertilizers and area of cultivated land) were obtained from the Natural Resources Institute of Finland. Maximum ice extent data for the Baltic Sea (MIB) was provided by the Finnish Meteorological Institute (30-year moving average with error range indicated for the early estimates), and the summer temperature record for the city of Turku (shown as 11-year running mean) was retrieved from Tuomenvirta et al. (2015). The population growth curve for the city of Turku was compiled from Lahtinen (2014) and data provided by the Population Register Centre of Finland.

cumulated during this period, the basin was $\sim 7 \mathrm{~m}$ deeper around $1000 \mathrm{AD}$ than at present (Fig. 7a). In addition, the intensive sediment focusing and drift-like deposition of the brackish-water muds has likely smoothed the bottom topography (Virtasalo et al., 2007), which has further decreased the bottom water volume towards present times upon pro- 
gressive basin infilling. The gradual shoaling of the basin has decreased the area located below the wave base, which in combination with the steep shoreline topography has increased the sediment source-to-sink ratio and led to more effective sediment focusing in the deepest parts of the basin towards the present (Fig. 7), as implied by the enhanced sediment MAR during the MoWP (Fig. 6).

Superimposed on this general trend towards calmer sedimentary conditions towards the present, climatic oscillations have exerted a prominent control on the bottom water hydrographic conditions at the study site. We ascribe the elevated $\mathrm{Ti} / \mathrm{K}$ and slightly coarser grain size during the MCA and MoWP in comparison to the LIA to enhanced bottom water currents and lateral sediment transport (Fig. 4; Spoffort et al., 2008), whereby the lack of ice cover in the late autumnearly winter promoted wave-induced sediment focusing upon exposure to storms (Fig. 7). Conversely, the early formation of ice cover during the LIA likely suppressed wind-induced mixing of the water column (Lincoln et al., 2016), thereby reducing the bottom water energy flux. Accordingly, it has been shown that a major proportion of the annual sediment accumulation in the Haverö occurs in late autumn and early winter due to the interplay of intensified cyclonic activity and lack of ice cover (Jokinen et al., 2015).

\subsection{Organic matter input}

\subsubsection{Source of the deposited organic matter}

The bulk sediment $\delta^{13} \mathrm{C}_{\text {org }}$ signature (from -23.9 to $-22.2 \%$ ) together with the low $\mathrm{C} / \mathrm{N}$ ratios (from 8.6 to 9.9) indicates that most of the OM deposited in the Haverö basin originates from autochthonous primary productivity rather than from terrestrial sources (e.g., Meyers, 1994, 1997), agreeing with the findings from analogous settings in the Swedish archipelago areas (Jönsson et al., 2005b; Savage et al., 2010; Ning et al., 2018). The marked positive correlation of BIT index and $\mathrm{C} / \mathrm{N}$ ratio as well as their negative correlation with $\delta^{13} \mathrm{C}_{\text {org }}$ (Fig. 5; Table 4) implies that all of these parameters are primarily sensitive to variations in the source of OM. Furthermore, the correlation of C / N and BIT (Fig. S2) also confirms that the two-end-member model of $\mathrm{C} / \mathrm{N}$ ratios is sufficient to trace OM provenance. Hence, it can be concluded that either the $\mathrm{C} / \mathrm{N}$ ratios of soil and vascular plantderived $\mathrm{OM}$ are rather similar in this system, and/or that their relative contribution has remained constant over time. The mixing model suggests that, on average, $23 \%$ (range from 15 to $32 \%$ ) of the sediment $\mathrm{C}_{\text {org }}$ originates from terrestrial sources, with the highest contribution being reached when the amount of phytoplankton-derived $\mathrm{C}_{\text {org }}$ is at minimum (Fig. 5). Similarly, conversion of the BIT index values to percentages of terrestrial (soil) $\mathrm{OM}\left(\% \mathrm{OM}_{\text {terr }}=100 \cdot \mathrm{BIT}\right)$ yields an average estimate of $22 \%$ (range from 18 to $29 \%$ ). These figures are in line with the $\mathrm{C} / \mathrm{N}$-based estimates of $\sim 20 \%$ for $\% \mathrm{OC}_{\text {terr }}$ in the middle parts of the archipelago area south of the Pojo Bay, in the Gulf of Finland (Jilbert et al., 2018). Collectively, these observations demonstrate that the changes in OM deposition are mainly controlled by variations in the autochthonous, phytoplankton-derived input.

We note that the excessively old bulk sediment radiocarbon dates for the $\mathrm{NaOH}$-soluble fraction suggest a marked input of old reworked OM (Fig. 2). Despite this contribution of pre-aged carbon, likely related to intensive reworking and lateral sediment advection in the basin (Jokinen et al., 2015), we assume that the $\mathrm{C}_{\text {org }}$ content and $\delta^{13} \mathrm{C}_{\text {org }}$ signature of the redeposited material have remained relatively constant, because this material represents a spatial and temporal mixture of sediments deposited in the area (Struck et al., 2000). The enclosed configuration of the basin throughout the study interval suggests that the majority of OM that has ultimately settled at our study site likely originates from a rather small area, and thus the observed increases in $\mathrm{OM}$ accumulation are likely caused by local enhanced productivity. Nevertheless, the intensive reworking and lateral sediment transport is likely to dilute and smooth the signal of the delivery of $\mathrm{OM}$ sourced from the contemporaneous local primary productivity in the euphotic zone, partly explaining the generally subtle variability in the sediment $\mathrm{C} / \mathrm{N}$ and $\delta^{13} \mathrm{C}_{\text {org }}$ profiles.

\subsubsection{Temporal fluctuations in the organic matter input}

Although inferences about past productivity based solely on the phytoplankton-derived $\mathrm{C}_{\text {org }}$ content of sediments are limited by potential dilution and preservation issues, variable productivity remains the most likely explanation for the observations in Fig. 5. Specifically, the contribution of terrestrial OM remains rather constant throughout the record (Fig. 5), whereas the phytoplankton-derived component is greater during the MCA and MoWP than during the LIA, implying variable input of phytoplankton material over time. This variable input likely controls the bulk sediment BIT, $\mathrm{C} / \mathrm{N}$, and $\delta^{13} \mathrm{C}_{\text {org }}$, which all show concordant trends. We note also that productivity and preservation effects often reinforce one another, since increased delivery of OM to the sediments is likely to stimulate preservation through decreased bottom water oxygenation (e.g., Pedersen and Calvert, 1990). Hence, in the following we interpret the content of phytoplankton-derived $\mathrm{OM}$ as a first-order estimate of changes in productivity over the studied interval. However, an important distinction is that $\mathrm{C}_{\text {org }}$ MAR is not only a function of productivity, but also of changes in sedimentation processes such as focusing. These become especially important at our study site in the later part of the record.

The fluctuations in the input of phytoplankton-derived OM to the basin generally coincide with the past climatic oscillations (Fig. 5) and with paleoproductivity records from the Baltic Proper (Leipe et al., 2008; Kabel et al., 2012; Jilbert and Slomp, 2013). Indeed, the MCA and MoWP are typified by relatively high input in comparison to the LIA, implying enhanced productivity under warm climatic phases. How- 


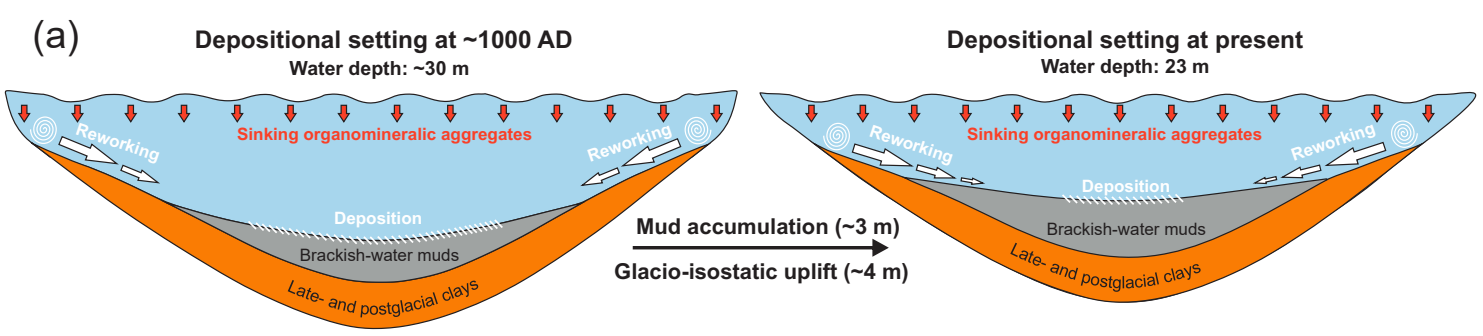

(b)

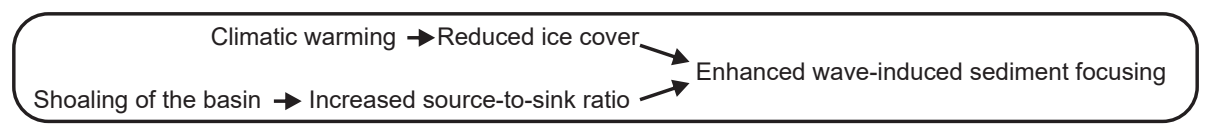

Figure 7. (a) Conceptual illustration of the sedimentation dynamics and changes in basin configuration at the study site from $1000 \mathrm{AD}$ to the present. The combination of glacio-isostatic uplift and accumulation of brackish-water muds has resulted in shoaling of the basin and increase in source-to-sink ratio. (b) Description of the effects of climatic warming and basin shoaling on sediment focusing at the study site.

ever, we note that $\delta^{13} \mathrm{C}_{\text {org }}$ and the MAR of $\mathrm{C}_{\text {org }}$ during the MCA remained below the MoWP values, indicating that the export production of $\mathrm{OM}$ and consequent sediment focusing never reached the MoWP levels. By contrast, a distinct decrease in $\mathrm{C}_{\text {org }}$ and $\delta^{13} \mathrm{C}_{\text {org }}$, paralleled by an increase in $\mathrm{C} / \mathrm{N}$ and the BIT index, coincides with the MCA-LIA transition (Fig. 5), suggesting that this marked decline in local primary productivity was most likely forced by the climatic cooling (Kabel et al., 2012).

The temporal trend in OM input observed in our data is similar to the trend in temperature recorded in millennialscale regional climate model simulations (Schimanke et al., 2012), and with dendroclimatic summer temperature reconstructions for southeastern Finland (Helama et al., 2014) as well as with a $\mathrm{TEX}_{86}$-derived sea surface temperature reconstruction for the Baltic Proper (Kabel et al., 2012). All of these studies report a decline in temperatures at $\sim 1300$ $1400 \mathrm{AD}$ with a persistently cold period lasting until the late 19th century, similarly to the fluctuations in the OM input at our study site (Fig. 5). Furthermore, the period of lowest productivity at $\sim 1700-1900 \mathrm{AD}$, as indicated by the maximum values in $\mathrm{C} / \mathrm{N}$ and BIT and concurrent minimum in the $\delta^{13} \mathrm{C}_{\text {org }}$ signature, is sympathetic with a minimum in summer temperatures in southeastern Finland (Fig. 5; Helama et al., 2014).

Importantly, we note that the long-term trends in land use and precipitation in the catchment show no similarity to our record of phytoplankton-derived OM input prior to the MoWP, suggesting that external nutrient inputs did not force past increases in productivity. Indeed, in agreement with the population growth records for Finland (Kuosmanen et al., 2016, and references therein), marked human-induced land-use changes in the catchments of varved lakes in southwestern and south-central Finland became discernible at $\sim 1400$ AD (Tiljander et al., 2003; Ojala and Alenius, 2005). This interval coincides with the onset of the LIA, during which both precipitation (Väliranta et al., 2007; Helama et al., 2009; Luoto, 2009; Saarni et al., 2015) and soil erosion rate (Tiljander et al., 2003; Ojala and Alenius, 2005; Saarni et al., 2016) increased in south-central Finland. However, this period is characterized by a shift to suppressed primary productivity at our study site, implying no influence of enhanced external nutrient inputs. The lack of anthropogenic forcing of OM input during the MCA is also in line with a recent paleoenvironmental reconstruction from the eastern coast of Sweden in the western part of the Baltic Proper (Ning et al., 2018), where no substantial signs of intensified land use were detected prior to 1400 AD. Finally, indirect anthropogenic influence via nutrient transport from the Baltic Proper, claimed to have received considerable human-induced nutrient loading already during the MCA (Zillén and Conley, 2010), is unlikely as the nutrient input in the study area is mainly driven by the local nutrient sources (Hänninen et al., 2000) due to the restricted water exchange with the open-sea areas (Mälkki et al., 1979).

The progressive increase in the $\delta^{15} \mathrm{~N}$ values, beginning already before the turn of the 20th century, attests to recent increased anthropogenic nutrient loading from agriculture and urban sources to the Baltic Sea (Voss and Struck, 1997; Struck et al., 2000; Voss et al., 2000, 2005; Savage et al., 2010). This is supported by the contemporaneous exponential population increase in Turku, which combined with the construction of a sewer network for the city likely enhanced sewage loading to the Archipelago Sea (Fig. 6). Yet, we observe negligible changes in the source of $\mathrm{OM}$ around $1900 \mathrm{AD}$, as implied by the relatively constant C / N and $\delta^{13} \mathrm{C}$ values (Fig. 6). This suggests that the enhanced anthropogenic nutrient influx alone was insufficient to explain the strong increase in the $\mathrm{C}_{\text {org }}$ MAR at this time. Therefore, we infer that the OM accumulation was markedly amplified by intensified sediment focusing from 1900 AD onwards, as supported by the contemporaneous increases in $\mathrm{Ti} / \mathrm{K}$ and sediment MAR sympathetic with a marked decline in the Baltic Sea ice extent (Figs. 4 and 6). We propose that the 
general trend towards higher source-to-sink ratio in the basin combined with the climate-driven intensification of windinduced sediment reworking (Fig. 7) to increase the $\mathrm{C}_{\text {org }}$ MAR to the sediments. This enhanced focusing likely promoted accumulation of variably degraded OM comprising a mixture from labile to more refractory material.

By contrast to the increase in $\mathrm{OM}$ accumulation in the early 20th century, the shift to unprecedentedly heavy $\delta^{13} \mathrm{C}$ signature, sympathetic with a decrease in $\mathrm{C} / \mathrm{N}$ and the BIT index around $1950 \mathrm{AD}$ (Fig. 6), points to markedly enhanced export production of phytoplankton-derived OM at this time (Meyers, 1994, 1997; Hopmans et al., 2004). This later shift was likely fueled by the concomitant substantial increase in nutrient loading from urban and agricultural sources in the catchment (Fig. 6), being in line with eutrophication trajectories elsewhere in the Baltic Sea linked to amplified anthropogenic nutrient inputs (Struck et al., 2000; Conley et al., 2009a; Savage et al., 2010; Gustafsson et al., 2012; Carstensen et al., 2014a). Finally, we infer that while $\mathrm{C}_{\text {org }}$ MAR during the MoWP has clearly exceeded the MCA levels (Fig. 5), the intensive sediment focusing and ballasting effects (Sect. 6.3.2) are likely to have diluted $\mathrm{C}_{\text {org }}$ content over the 20th century.

\subsection{Changes in hypoxia intensity and its causes}

\subsubsection{Bottom water oxygenation prior to the Modern Warm Period}

The intensive Planolites mottling that completely overprints the primary sedimentary fabric (bioturbation index 4) in the pre-MCA sediments clearly demonstrates efficient ventilation of the bottom waters, which enabled macrobenthic fauna to inhabit the seafloor (Figs. 3a and 4). The scarcity of discrete traces in this sediment interval could be attributed to less intense pyritization along the burrow walls than in the overlying sediments (Thomsen and Vorren, 1984) and to the overlapping of densely spaced burrows (Virtasalo et al., 2011a, b). Macrofauna living in the area and capable of completely mixing the seafloor sediment include the isopod Saduria entomon, the polychaete Harmothoe sarsi, the amphipods Monoporeia affinis and Pontoporeia femorata, and the mysid shrimp Mysis relicta. The discrete Planolites are produced by vermiform burrowers such as the priapulid Halicryptus spinulosus.

The enhanced preservation of the thinly bedded sedimentary fabric during the MCA at $\sim 900-1200 \mathrm{AD}$, as demonstrated by the decrease in the bioturbation index (Figs. 3b and 4), is indicative of declining near-bottom oxygen levels during this period. The poorly developed grading of these beds is ascribed to the predominantly lateral sediment transport in the basin (Jokinen et al., 2015) and possibly results from the slow migration of thin accretionary bedforms. The dominance of Planolites with a small diameter and vertical extent in the trace fossil assemblage together with the sub- tle decrease in the bioturbation index (Fig. 4) demonstrate low burrowing activity under a considerable oxygen stress (Savrda and Bottjer, 1986, 1991), especially during the first half of the MCA.

Despite the decline in the bottom water oxygen concentration during the MCA, we infer that the pore water chemistry was typified by a relatively deep and poorly developed SMTZ with low $\mathrm{H}_{2} \mathrm{~S}$ concentration, which hampered efficient Mo sequestration (Helz and Adelson, 2013) and Ph production by methanogenic microbes (Sect. 6.3.2). This could explain why the Mo and $\mathrm{Pr} / \mathrm{Ph}$ profiles fail to record the modest deoxygenation during the MCA indicated by the trace fossil data. Since $\sim 1200 \mathrm{AD}$, the increases in the bioturbation index and in the abundance of Arenicolites trace fossils, characterized by generally larger size and greater vertical extent than Planolites, denote enhanced bottom water oxygenation and a downward shift of the SMTZ, continuing throughout the LIA (Figs. 3c and 4). Indeed, the greater burrow depth and size suggests a downward shift in the annual mean depth of the redoxcline during this period (Savrda and Bottjer, 1986, 1991).

We attribute the multicentennial-scale fluctuations in bottom water oxygenation associated with the MCA and LIA to climatic variability that modulated both hydrographic conditions and accumulation of $\mathrm{OM}$ at the seafloor. This is supported by the $\mathrm{Ti} / \mathrm{K}$ and grain size profiles and the organic matter proxies (Sect. 6.1 and 6.2) that indicate amplified lateral sediment transport (focusing) and primary productivity during the MCA in comparison to the LIA (Figs. 4 and 5). In addition, we note a slight decrease in LSR at $\sim 1380 \mathrm{AD}$ (Fig. 2), coinciding with the MCA-LIA transition. The temporal pattern is similar to the development of hypoxia in the Baltic Proper (Jilbert and Slomp, 2013; Funkey et al., 2014; Jilbert et al., 2015; Dijsktra et al., 2016; Hardisty et al., 2016; Papadomanolaki et al., 2018) and in the Danish straits (van Helmond et al., 2017), where warm climatic phases during the Holocene have been characterized by declining oxygen levels. Yet, we note that the amplitude of these changes appears markedly less pronounced at our study site, which is most likely attributed to the lack of permanent halocline in this shallow coastal region. Collectively, the similar trends in the intensity of hypoxia in different parts of the Baltic Sea basin attest to regional forcing that was most likely related to changes in the atmospheric circulation patterns such as the NAO, as suggested by Jilbert and Slomp (2013).

\subsubsection{Progressive intensification of hypoxia during the Modern Warm Period}

The MAR of Mo in the sediments at our study site increased during the MoWP (Fig. 6). Due to the fact that the study site is seasonally hypoxic, rather than permanently anoxic or euxinic, the most likely mechanism for Mo enrichment is via diffusion of seawater Mo into the sediment towards the SMTZ (see Helz and Adelson, 2013), which may be ampli- 
fied by the shuttling of Mo associated with Mn oxides (Algeo and Lyons, 2006; Scheiderich et al., 2010; Scott and Lyons, 2012; Sulu-Gambari et al., 2017). It is thus plausible that the scavenging of Mo mostly takes place close to the sediment surface at the end of summer stratification period when the SMTZ reaches its shallowest position in the sediment column (Mogollón et al., 2011) and shuttling and refluxing of Mn is expected to be at its annual maximum. Indeed, total sulfide concentrations of $>600 \mu \mathrm{M}$ have been reported to prevail in the uppermost centimeters of the sediment column within the SMTZ at the study site (Karoliina Koho, University of Helsinki, personal communication, 2018). Assuming a salinity and temperature of 5.6 and $9{ }^{\circ} \mathrm{C}$, respectively (Virtasalo et al., 2005), and a $\mathrm{pH}$ of 6.6 (our unpublished data) at the sediment-water interface, this total sulfide concentration corresponds to a $\mathrm{H}_{2} \mathrm{~S}_{\mathrm{aq}}$ concentration of $>400 \mu \mathrm{M}$ (calculated with R package AquaEnv, Hoffmann et al., 2010), clearly exceeding the requirement of $11 \mu \mathrm{M} \mathrm{H}_{2} \mathrm{~S}_{\mathrm{aq}}$ for the activation of the sulfide switch (Helz et al., 1996; Erickson and Helz, 2000). The annual accumulation rate of Mo is expected to be controlled by the duration of the late summer period when the SMTZ is located closest to the sediment surface (Adelson et al., 2001; Helz and Adelson, 2013), which, in turn, is modulated by the balance between the delivery of labile OM and electron acceptors at the seafloor (Middelburg and Levin, 2009). By extension, when this period is longer in duration we expect seasonal hypoxia in the bottom water to be more intense and thus that the Mo accumulation rate provides a first-order proxy for bottom water hypoxia during the MoWP. We note that the amount of anthropogenically sourced Mo in our sediment record is likely negligible in comparison to the enrichment caused by authigenic processes. Indeed, it has been shown that modern sediment sequestration of Mo in the area shows no spatial trends but is largely controlled by bottom water oxygenation (Peltola et al., 2011). Furthermore, the similarity between raw Mo content and Mo / Al profiles (Fig. S3) implies that the sediment Mo content at the study site is determined by authigenic Mo sequestration.

During the MoWP, the Haverö basin has undergone a progressive aggravation of bottom water hypoxia, typified by two distinct regime shifts. First, a marked shoaling of the sediment redoxcline at $1900 \mathrm{AD}$ is manifested in the contemporaneous occurrence of continuous lamination (near-complete cessation of macrobenthic activity), a decrease in $\mathrm{Pr} / \mathrm{Ph}$, and an increase in the MAR of Mo (Fig. 6). Although the onset of the increased Mo MAR is hard to constrain due to the scarcity of age constraints prior to the preservation of continuous laminations, the appearance of subtle enrichments in Mo content evidences intermittent shoaling of the SMTZ and consequently intensified sequestration of Mo in the sediments since 1900 AD (Adelson et al., 2001; Helz and Adelson, 2013). Likewise, the preservation of laminated sedimentary fabric suggests upward migration of the redoxcline towards the sediment-water interface, inhibiting burrowing by macroinfauna, whereas the occasional blurring of lami- nations (Fig. 3d) is ascribed to subtle mixing by meiofauna or transient colonization by opportunistic nectobenthos (Virtasalo et al., 2011b; Jokinen et al., 2015). Although annual recovery of macrofauna is common to systems prone to recurring seasonal hypoxia (Diaz and Rosenberg, 1995; Levin et al., 2009), such rapid recolonization was effectively inhibited in the Haverö basin since $1900 \mathrm{AD}$, possibly owing to increased porewater $\mathrm{H}_{2} \mathrm{~S}$ concentration (Diaz and Rosenberg, 1995). A critical threshold for defaunation in areas experiencing seasonal hypoxia is often around $0.7 \mathrm{mg} \mathrm{L}^{-1}$ (Llansó, 1992; Diaz and Rosenberg, 1995), pointing to severe nearbottom water oxygen depletion at the study site already at 1900 AD.

Considering the negligible variation in the proxies for the source of OM prior to $1930 \mathrm{AD}$ (Fig. 6), the onset of seasonal hypoxia and the resulting preservation of continuous lamination since the beginning of 20th century was apparently not solely forced by potential changes in primary productivity linked to human-induced eutrophication. Instead, we postulate that this deoxygenation was forced by the following complex interplay of factors: (1) increased source-to-sink ratio, combined with intensified lateral sediment transport especially during early winter due to the warming climate, leading to enhanced sediment focusing and higher MAR of $\mathrm{C}_{\text {org }}$ (Fig. 7; Sect. 6.2.2) - together with the prior accumulation of organic-rich brackish-water muds in the basin at least since $\sim 500 \mathrm{AD}$, this likely led to progressive depletion of electron acceptors ("oxygen debt") at the seafloor (Pamatmat, 1971); (2) decreased bottom water volume due to the gradual shoaling of the basin, resulting in increased vulnerability to hypoxia (Caballero-Alfonso et al., 2015); (3) strengthened summer thermocline caused by global warming and gradual isolation of the basin hampered the replenishment of the bottom water oxygen reservoir (Hordoir et al., 2017); (4) increased anthropogenic nutrient loading from the catchment potentially stimulated primary productivity and the delivery of OM to the seafloor (Sect. 6.2.2). Accordingly, the onset of recurring seasonal hypoxia at around $1900 \mathrm{AD}$ can be at least partly attributed to the naturally increased vulnerability to deoxygenation, which alongside global warming and direct anthropogenic forcing irreversibly tipped the ecosystem over a threshold, inducing a regime shift commonly associated with coastal oxygen deficiency (e.g., Conley et al., 2009b).

Another marked redox shift is observed at $1950 \mathrm{AD}$, where a rapid increase in Mo MAR accompanied by a prominent decrease in $\mathrm{Pr} / \mathrm{Ph}$ suggest unprecedentedly reducing conditions at the sediment-water interface (Fig. 6). This shift likely denotes shoaling of the redox zonation as a response to eutrophication in the area, which has been reported in previous studies of the Baltic Sea (Slomp et al., 2013; Egger et al., 2015; Rooze et al., 2016; Jilbert et al., 2018) and reflects intensified delivery of labile OM to the seafloor with respect to the supply of electron acceptors (Middelburg and Levin, 2009). Considering the decreasing trend in the local 
summer temperatures over this interval, promoting less intense sediment focusing, weaker thermal stratification, and suppressed productivity, we infer that the upward migration of the SMTZ was more likely driven by the increased anthropogenic nutrient loading from the catchment than by climatic factors (Fig. 6). Similar exacerbation of bottom water hypoxia around the 1950s has been reported in the coastal areas of Sweden (Persson and Jonsson, 2000; Savage et al., 2010) and in the Baltic Proper (Fig. 6; Jonsson et al., 1990; Carstensen et al., 2014a), reflecting synchronous increases in the anthropogenic nutrient loading around the Baltic Sea (Conley et al., 2009a; Savage et al., 2010; Gustafsson et al., 2012; Carstensen et al., 2014a). This deoxygenation around the 1950s conforms to the global spread of hypoxia in coastal areas (Vaquer-Sunyer and Duarte, 2008) following the "Great Acceleration" (Steffen et al., 2015). Accordingly, the steepest gradient in the $\delta^{15} \mathrm{~N}$ profile at our study site is reached between 1950 and $1995 \mathrm{AD}$, paralleled by intensified agricultural practices and fast population growth rate (Fig. 6).

Although the decline in Mo content and concomitant increase in $\mathrm{Pr} / \mathrm{Ph}$ suggest a slight improvement in the bottom water oxygenation since $1990 \mathrm{AD}$ (Fig. 6), this is an unlikely scenario. Instead, the MAR of Mo has remained high since $1950 \mathrm{AD}$ and reached the highest values of the record as late as $2005 \mathrm{AD}$, suggesting that aggravation of bottom water hypoxia has continued up to the present, as evidenced by the local monitoring data directly at the study site (Fig. S4). In line with this, monitoring data in other parts of the Archipelago Sea consistently demonstrate progressive deoxygenation in the area during last two decades (Fig. 8; Suomela, 2011; Caballero-Alfonso et al., 2015). Therefore, we ascribe the decrease in Mo content at $1990 \mathrm{AD}$ to dilution by the concurrently enhanced sediment MAR (Fig. 6). We postulate that, in addition to effective sediment focusing, the increased sediment MAR was likely fueled by ballasting effects, whereby eutrophication-induced increase in the OM production in the euphotic zone drives the sedimentation of fine-grained lithogenic material through aggregation (Passow, 2004; Passow and De La Rocha, 2006; De La Rocha et al., 2008), as suggested by the close covariation between sediment and $\mathrm{C}_{\text {org }}$ MARs (Fig. 6). In line with this, it has been shown that rapid sedimentation events during vernal phytoplankton blooms in the study area are caused by the formation of organomineralic aggregates adhered together by sticky transparent exopolymers (TEP) excreted by phytoplankton (Jokinen et al., 2015), coupling the sedimentation of lithogenic material to autochthonous primary production. Therefore, while $\mathrm{C}_{\text {org }}$ content remained fairly constant over the shift to enhanced sediment MAR at 1985 AD due to intensified sediment focusing and ballasting effects, the content of Mo was diluted as the depth and intensity of the $\mathrm{H}_{2} \mathrm{~S}$ front remained relatively unaffected.

The recovery in $\mathrm{Pr} / \mathrm{Ph}$ at the core top (Fig. 6), which is observed despite the obvious aggravation of hypoxia until the present, suggests that the distinct minimum in $\mathrm{Pr} / \mathrm{Ph}$ be-

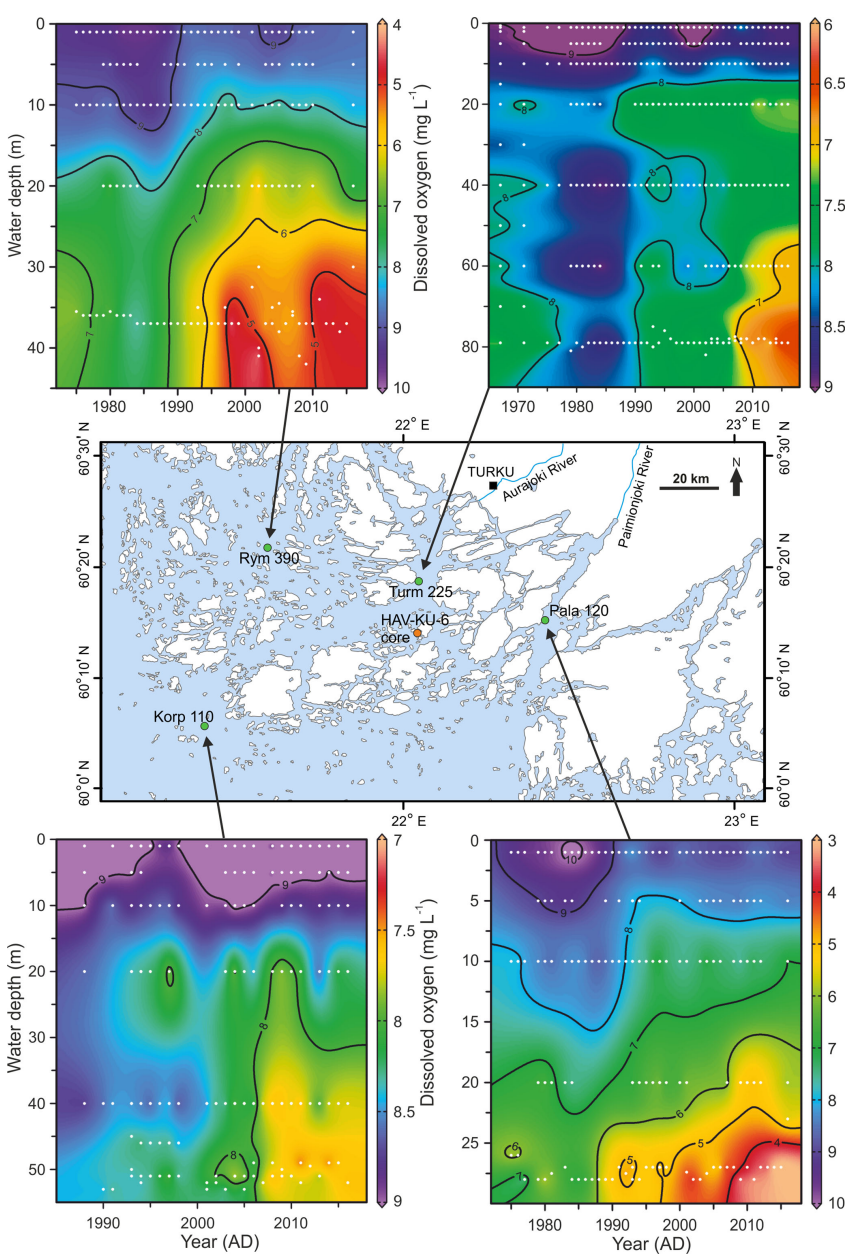

Figure 8. Contour plots for water column dissolved oxygen concentration in August over the past decades at four intensive monitoring stations (data from HERTTA database) located around the study site (HAV-KU-6). The interpolations were produced with the Ocean Data View software (Schlitzer, 2017). White dots represent the original measurement data.

tween $1950(53.5 \mathrm{~cm})$ and $1990 \mathrm{AD}(29 \mathrm{~cm})$ is caused by a post-depositional overprint. Although the mechanism causing a diagenetic decline in $\mathrm{Pr} / \mathrm{Ph}$ in this depth interval at the present day remains speculative, a likely candidate is the excess $\mathrm{Ph}$ production by methanogenic microbes (Brassel et al., 1981; Venkatesan and Kaplan, 1987; Duan, 2000). Indeed, the current position of the SMTZ at our study site is likely located in the uppermost $10-20 \mathrm{~cm}$ below the sediment surface (see Sawicka and Brüchert, 2017 and Jilbert et al., 2018, for comparable systems), below which methane concentrations are expected to increase to the millimolar range. As such, $\mathrm{Pr} / \mathrm{Ph}$ may not be a direct proxy for bottom water oxygenation at our study site. Instead, it likely records the rate of methanogenesis below the SMTZ, reflecting the amount of labile OM that escapes aerobic degradation. Importantly, the invariably high $\mathrm{Pr} / \mathrm{Ph}$ prior to the 20th century (Fig. 4) could 
denote that intensive methane formation, due to increased productivity and subsequent shoaling of the redox zonation over the past few decades (Slomp et al., 2013; Egger et al., 2015; Rooze et al., 2016; Jilbert et al., 2018), is unprecedented in our sediment record. However, the low Mo content of $<10 \mathrm{mg} \mathrm{kg}^{-1}$ (Fig. 6) suggests that the basin has remained non-euxinic until the present (Scott and Lyons, 2012). This is also evidenced by the slope of $\sim 2.7$ for the linear regression between Mo and $\mathrm{C}_{\mathrm{org}}$ (Fig. S1), being slightly shallower than reported for continental margin upwelling systems characterized by persistently hypoxic, but non-euxinic bottom water conditions (Algeo and Rowe, 2012, and references therein). Furthermore, the MAR of Mo has remained in less than half of the MAR reported for the seasonally mildly euxinic Chesapeake Bay (Helz and Adelson, 2013).

\section{Implications}

Previous studies have suggested that the eutrophication of the Archipelago Sea began in the late 1960s (Bonsdorff et al., 1997a, b; Hänninen et al., 2000; Suomela, 2011). Our data show that environmental conditions around the study site in the Archipelago Sea likely deteriorated several decades prior to this and therefore also prior to the establishment of water quality monitoring campaigns in the 1960s. This highlights the use of sediment-core studies for the long-term reconstruction of environmental conditions in such settings. Our $\delta^{15} \mathrm{~N}$ record demonstrates increased anthropogenic nutrient input already at the beginning of the 20th century (Fig. 6), although the onset of hypoxia and laminated sediment deposition at this time was additionally driven by physical factors (Sect. 6.3.2). However, the prominent aggravation of hypoxia in the 1950s was unequivocally anthropogenically induced. The timing of this shift predates the major establishment period of fish farms in the Archipelago Sea in 1970s (Hänninen et al., 2000), suggesting that, although aquaculture has aggravated hypoxia since the 1970s (Bonsdorff et al., 1997a), other human activities had significantly degraded the coastal water quality up to 20 years previously.

Despite the decreased loading of sewage waters since the 1980s, following the establishment of a wastewater treatment plant for the city of Turku (Suomela, 2011; Fig. 6), the continued leakage of nutrients from agriculture to the Archipelago Sea (Ekholm et al., 2015) together with intensive $\mathrm{P}$ regeneration from surface sediments mainly upon the dissolution of Fe-bound P (Puttonen et al., 2014) has sustained the trend toward increasing eutrophication and shoaling of hypoxia until the present (Figs. 6 and 7). In addition, the recent trajectory towards further aggravation of hypoxia has likely been amplified by the progressively increasing summer temperatures (Fig. 6), which is also supported by the increased importance of climatic effects in the forcing of oxygen depletion in the Swedish coast of the Baltic Sea since the late 1970s (Savage et al., 2010). Hence, while reductions in nutrient loading appear to have improved bottom water oxygenation in the Stockholm Archipelago since the 1990s (Karlsson et al., 2010), we observe no signs of recovery in the Archipelago Sea so far.

\section{Conclusions}

This study shows that multicentennial-scale climatic oscillations affect near-bottom water oxygenation of a shallow coastal basin in the northern Baltic Sea currently suffering from severe seasonal hypoxia. During warm phases, increased export production of labile, phytoplankton-derived OM combined with effective sediment focusing to the deepest part of the basin drives deoxygenation of the near-bottom waters in summer. Accordingly, decreased oxygen levels are observed during the MCA and MoWP, but the intensity of the MoWP hypoxia, typified by complete deterioration of the macrobenthic community, is unprecedentedly severe. The progressive deoxygenation during the 1900s was originally triggered by gradual shoaling of the basin due to glacioisostatic uplift and basin infilling that, together with warming climate and anthropogenic nutrient input, promoted the vulnerability of the basin to hypoxia and intensified OM accumulation. By contrast, the marked aggravation of hypoxia in the 1950s was unequivocally attributed to the excessive anthropogenic nutrient loading from the catchment, which substantially stimulated autochthonous primary production. Our results demonstrate that the markedly more severe hypoxia during the MoWP in comparison to the MCA is not only attributed to the excess anthropogenic nutrient loading, but also to the gradual changes in the basin configuration that have increased the sensitivity to deoxygenation towards the present. Such natural changes should be considered when elucidating anthropogenic contribution to hypoxia. Furthermore, signs of eutrophication in the area are readily discernible in our sediment record already in the beginning of 1900s, implying that the water quality diverged from natural conditions decades prior to the establishment of monitoring campaigns. This has important implications for the assessment of reference conditions for water quality in the area. Despite the recent measures taken to reduce anthropogenic nutrient loading to the area, we find no evidence of recovery from hypoxia, suggesting that further measures are needed to alleviate oxygen depletion.

Data availability. The data we have produced ourselves can now be found in Pangaea: https://doi.pangaea.de/10.1594/PANGAEA. 891284. In cases where data from a third party were used, this has been clearly indicated in the figure captions.

Supplement. The supplement related to this article is available online at: https://doi.org/10.5194/bg-15-3975-2018-supplement. 
Author contributions. SJ devised the study, conducted field and laboratory work, interpreted the data, produced the figures, and drafted the paper. JV devised the study, interpreted the data, and assisted with trace fossil analysis and writing the paper. TJ assisted with laboratory work, interpreted the data, and assisted with writing the paper. JK assisted with the biomarker analyses, interpreted the data, and assisted with writing the paper. OD carried out the ICP-OES and ICP-MS analyses at IOW, interpreted the data, and assisted with writing the paper. HA interpreted the data and assisted with writing paper. JH conducted fieldwork, interpreted the data, and assisted with writing the paper. LA carried out the IRMS analysis and assisted with writing the paper. MC assisted with the ICPOES analysis in Helsinki. TS conducted field and laboratory work and assisted with writing the paper.

Competing interests. The authors declare that they have no conflict of interest.

Acknowledgements. We acknowledge the crew on R/V Aurelia for their valuable help in sediment coring. Nadine Hollman, Anne Köhler, Arto Peltola, Jouko Saren, and Hannu Wenho are thanked for their assistance with the laboratory work. Ilppo Vuorinen is thanked for stimulating discussions on the eutrophication of the Archipelago Sea. This research was funded by the Finnish Cultural Foundation project 00150315, Maa- ja Vesitekniikan Tuki project 32719 , and by the BaltRap project SAW-2017-IOW-2, which was funded by the Leibniz Association. SJ received funding from the Doctoral Programme in Biology, Geography and Geology (BGG) at the University of Turku. This study has utilized research infrastructure facilities provided by FINMARI (Finnish Marine Research Infrastructure network).

Edited by: S. W. A. Naqvi

Reviewed by: two anonymous referees

\section{References}

Adelson, J. M., Helz, G. R., and Miller, C. V.: Reconstructing the rise of recent coastal anoxia; molybdenum in Chesapeake Bay sediments, Geochim. Cosmochim. Ac., 65, 237-252, https://doi.org/10.1016/S0016-7037(00)00539-1, 2001.

Algeo, T. J. and Lyons, T. W.: Mo-total organic carbon covariation in modern anoxic marine environments: Implications for analysis of paleoredox and paleohydrographic conditions, Paleoceanography, 21, PA1016, https://doi.org/10.1029/2004PA001112, 2006.

Algeo, T. J. and Rowe, H.: Paleoceanographic applications of trace-metal concentration data, Chem. Geol., 324, 6-18, https://doi.org/10.1016/j.chemgeo.2011.09.002, 2012.

Almroth-Rosell, E., Edman, M., Eilola, K., Meier, H. E. M., and Sahlberg, J.: Modelling nutrient retention in the coastal zone of an eutrophic sea, Biogeosciences, 13, 5753-5769, https://doi.org/10.5194/bg-13-5753-2016, 2016.

Altabet, M. A. and Francois, R.: Sedimentary nitrogen isotopic ratio as recorder for surface ocean nitrate utilization, Global Biogeochem. Cy., 8, 103-116, https://doi.org/10.1029/93GB03396, 1994.
Altabet, M. A., Deuser, W. G., Honjo, S., and Stienen, C.: Seasonal and depth-related changes in the source of sinking particles in the North Atlantic, Nature, 354, 136-139, https://doi.org/10.1038/354136a0, 1991.

Aravena, R., Evans, M. L., and Cherry, J. A.: Stable isotopes of oxygen and nitrogen in source identification of nitrate from septic systems, Ground Water, 31, 180-186, https://doi.org/10.1111/j.1745-6584.1993.tb01809.x, 1993.

Asmala, E., Carstensen, J., Conley, D. J., Slomp, C. P., Stadmark, J., and Voss, M.: Efficiency of the coastal filter: Nitrogen and phosphorus removal in the Baltic Sea, Limnol. Oceanogr., 62, S222-S238, https://doi.org/10.1002/lno.10644, 2017.

Bedrock of Finland - DigiKP: Digital Map Database (Electronic source), Geological Survey of Finland, available at: http:// gtkdata.gtk.fi/Kalliopera/index.html, last access: 8 June 2017.

Behl, R. J. and Kennett, J. P.: Brief interstadial events in the Santa Barbara basin, NE Pacific, during the past $60 \mathrm{kyr}$, Nature, 379, 243-246, https://doi.org/10.1038/379243a0, 1996.

Bonsdorff, E., Blomqvist, E. M., Mattila, J., and Norkko, A.: Coastal eutrophication: causes, consequences and perspectives in the archipelago areas of the northern Baltic Sea, Estuar. Coast. Shelf S., 44 (Suppl. A), 63-72, https://doi.org/10.1016/S02727714(97)80008-X, 1997a.

Bonsdorff, E., Blomqvist, E. M., Mattila, J., and Norkko, A.: Longterm changes and coastal eutrophication. Examples from the Alland Island and the Archipelago Sea, northern Baltic Sea, Oceanol. Acta, 20, 319-329, 1997b.

Brännvall, M.-L., Bindler, R., and Renberg, I.: The medieval industry was the cradle of modern large-scale atmospheric lead pollution northern Europe, Environ. Sci. Technol., 33, 4391-4395, https://doi.org/10.1021/es990279n, 1999.

Brassel, S. C., Wardroper, A. M. K., Thomson, I. D., Maxwell, J. R., and Eglinton, G.: Specific acyclic isoprenoids as biological markers of methanogenic bacteria in marine sediments, Nature, 290, 693-696, https://doi.org/10.1038/290693a0, 1981.

Bronk Ramsey, C.: Deposition models for chronological records, Quaternary Sci. Rev., 27, 42-60, https://doi.org/10.1016/j.quascirev.2007.01.019, 2008.

Bronk Ramsey, C.: Bayesian analysis of radiocarbon dates, Radiocarbon, 51, 337-360, https://doi.org/10.1017/S0033822200033865, 2009.

Caballero-Alfonso, A. M., Carstensen, J., and Conley, D. J.: Biogeochemical and environmental drivers of coastal hypoxia, J. Marine Syst., 141, 190-199, https://doi.org/10.1016/j.jmarsys.2014.04.008, 2015.

Carstensen, J., Andersen, J. H., Gustafsson, B. G., and Conley, D. J.: Deoxygenation of the Baltic Sea during the last century, P. Natl. Acad. Sci. USA, 111, 5628-5633, https://doi.org/10.1073/pnas.1323156111, 2014a.

Carstensen, J., Conley, D. J., Bonsdorff, E., Gustafsson, B. G., Hietanen, S., Janas, U., Jilbert, T., Maximov, A., Norkko, A., Norkko, J., Reed, D. C., Slomp, C. P., Timmermann, K., and Voss, M.: Hypoxia in the Baltic Sea: biogeochemical cycles, benthic fauna, and management, Ambio, 43, 26-36, https://doi.org/10.1007/s13280-013-0474-7, 2014b.

Cole, M. L., Valiela, I., Kroeger, K. D., Tomasky, G. L., Cebrian, J., Wigand, C., McKinney, R. A., Grady, S. P., and Carvalho da Silva, M. H.: Assesment of a $\delta^{15} \mathrm{~N}$ isotopic method to indicate 
anthropogenic eutrophication in aquatic ecosystems, J. Environ. Qual., 33, 124-132, https://doi.org/10.2134/jeq2004.1240, 2004.

Conley, D. J., Humborg, C., Rahm, L., Savchuk, O.P., and Wulff, F.: Hypoxia in the Baltic Sea and basin-scale changes in phosphorus biogeochemistry, Environ. Sci. Technol., 36, 5315-5320, https://doi.org/10.1021/es025763w, 2002.

Conley, D. J., Björck, S., Bonsdorff, E., Carstensen, J., Destouni, G., Gustafsson, B. G., Hietanen, S., Kortetaas, M., Kuosa, J., Meier, H. E. M., Müller-Karulis, B., Nordberg, K., Norkko, A., Nurnberg, G., Pitkänen, H., Rabalais, N. N., Rosenberg, R., Savchuck, O. P., Slomp, C. P., Voss, M., Wulff, F., and Zillén L.: Hypoxiarelated processes in the Baltic Sea, Environ. Sci. Technol., 43, 3412-3420, https://doi.org/10.1021/es802762a, 2009a.

Conley, D. J., Carstensen, J., Vaquer-Sunyer, R., and Duarte, C. M.: Ecosystem thresholds with hypoxia, Hydrobiologia, 629, 21-29, https://doi.org/10.1007/978-90-481-3385-7_3, 2009b.

Conley, D. J., Carstensen, J., Aigars, J., Are, P., Bonsdorff, E., Eremina, T., Haahti, B.-M., Humborg, C., Jonsson, P., Kotta, J., Lännegren, C., Larsson, U., Maximov, A., Medina, M. R., Lysiak-Pastuszak, E., Remekaite-Nikiene, N., Walve, J., Wilhelms, S., and Zillén, L.: Hypoxia increasing in the coastal zone of the Baltic Sea, Environ. Sci. Technol., 45, 6777-6783, https://doi.org/10.1021/es201212r, 2011.

Dahl, T. W., Chappaz, A., Fitts, J. P., and Lyons, T. W.: Molybdenum reduction in a sulfidic lake: Evidence from X-ray absorption fine-structure spectroscopy and implications for the Mo paleoproxy, Geochim. Coscmochim. Ac., 103, 213-231, https://doi.org/10.1016/j.gca.2012.10.058, 2013.

Dahl, T. W., Chappaz, A., Hoek, J., McKenzie, C. J., Svane, S., and Canfield, D. E.: Evidence of molybdenum association with particulate organic matter under sulfidic conditions, Geobiology, 15, 311-323, https://doi.org/10.1111/gbi.12220, 2017.

De La Rocha, C., Nowald, N., and Passow, U.: Interactions between diatom aggregates, minerals particulate organic carbon, and dissolved organic matter: Further implications for the ballast hypothesis, Global Biogeochem. Cy., 22, GB4005, https://doi.org/10.1029/2007GB003156, 2008.

Dellwig O., Hinrichs J., Hild A., and Brumsack H. J.: Changing sedimentation in tidal flat sediments of the southern North Sea from the Holocene to the present: a geochemical approach, J. Sea Res., 44, 195-208. https://doi.org/10.1016/S1385-1101(00)00051-4, 2000.

Diaz, R. J. and Rosenberg, R.: Marine benthic hypoxia: a review of its ecological effects and the behavioural responses of benthic macrofauna, Oceanogr. Mar. Biol., 33, 245-303, 1995.

Diaz, R. J. and Rosenberg, R.: Spreading of dead zones and consequences for marine ecosystems, Science, 321, 926-929, https://doi.org/10.1126/science.1156401, 2008.

Didyk, B. M., Simoneit, B. R. T., Brassell, S. C., and Eglinton, G.: Organic geochemical indicators of palaeoenvironmental conditions of sedimentation, Nature, 272, 216-222, https://doi.org/10.1038/272216a0, 1978.

Dijkstra, N., Slomp, C. P., Behrends, T., and Expedition 347 Scientists: Vivianite is a key sink for phosphorus in sediments of the Landsort Deep, an intermittently anoxic deep basin in the Baltic Sea, Chem. Geol., 438, 58-72, https://doi.org/10.1016/j.chemgeo.2016.05.025, 2016.
Duan, Y.: Organic geochemistry of recent marine sediments from the Nansha Sea, China. Org. Geochem., 31, 159-167, https://doi.org/10.1016/S0146-6380(99)00135-7, 2000.

Egger, M., Jilbert, T., Behrends, T., Rivard, C., and Slomp, C. P.: Vivianite is a major sink for phosphorus in methanogenic coastal surface sediments, Geochim. Coscmochim. Ac., 169, 217-235, https://doi.org/10.1016/j.gca.2015.09.012, 2015.

Ekholm, P., Rankinen, K., Rita, H., Räike, A., Sjöblom, H., Raateland, A., Vesikko, L., Bernal, J. E. C., and Taskinen, A.: Phosphorus and nitrogen fluxes carried by 21 Finnish agricultural rivers in 1985-2006, Environ. Monit. Assess., 187, 216 , https://doi.org/10.1007/s10661-015-4417-6, 2015.

Erickson, B. E. and Helz, G. R.: Molybdenum (VI) speciation in sulfidic waters: Stability and lability of thiomolybdates, Geochim. Coscmochim. Ac., 64, 1149-1158, https://doi.org/10.1016/S0016-7037(99)00423-8, 2000.

Fogel, M. L., Cifuentes, L. A., Velinsky, D. J., and Sharp, J. H.: Relationship of carbon availability in estuarine phytoplankton to isotopic composition, Mar. Ecol. Prog. Ser., 82, 291-300, 1992.

Freudenthal, T., Wagner, T., Wenzhöfer, F., Zabel, M., and Wefer, G.: Early diagenesis of organic matter from sediments of the eastern subtropical Atlantic: Evidence from stable nitrogen and carbon isotopes, Geochim. Coscmochim. Ac., 65, 1795-1808, https://doi.org/10.1016/S0016-7037(01)00554-3, 2001.

Funkey, C. P., Conley, D. J., Reuss, N. S., Humborg, C., Jilbert, T., and Slomp, C. P.: Hypoxia sustains cyanobacteria blooms in the Baltic Sea, Environ. Sci. Technol., 48, 2598-2602, https://doi.org/10.1021/es404395a, 2014.

Gälman, V., Rydberg, J., Sjöstedt de-Luna, S., Bindler, R., and Renberg, I.: Carbon and nitrogen loss rates during aging of lake sediment: changes over 27 years studied in varved lake sediment, Limnol. Oceanogr., 53, 1076-1082, https://doi.org/10.4319/lo.2008.53.3.1076, 2008.

Goñi, M., Teixeira, M., and Perkey, D.: Sources and distribution of organic matter in a river-dominated estuary (Winyah Bay, SC, USA), Estuar. Coast. Shelf S., 57, 1023-1048, https://doi.org/10.1016/S0272-7714(03)00008-8, 2003.

Gooday, A. J., Jorissen, F., Levin, L. A., Middelburg, J. J., Naqvi, S. W. A., Rabalais, N. N., Scranton, M., and Zhang, J.: Historical records of coastal eutrophication-induced hypoxia, Biogeosciences, 6, 1707-1745, https://doi.org/10.5194/bg-6-17072009, 2009.

Goslar, T., Czernik, J., and Goslar, E.: Low-energy 14C AMS in Poznań Radiocarbon Laboratory, Poland. Nucl. Instrum. Meth. B., 223-224, 5-11, https://doi.org/10.1016/j.nimb.2004.04.005, 2004.

Gustafsson, B. G., Schenk, F., Blenckner, T., Eilola, K., Meier, H. E. M., Müller-Karulis, B., Neumann, T., Ruoho-Airola, T., Savchuk, O. P., and Zorita, E.: Reconstructing the development of Baltic Sea eutrophication 1850-2006, Ambio, 41, 534-548, https://doi.org/10.1007/s13280-012-0318-x, 2012.

Hänninen, J., Vuorinen, I., Helminen, H., Kirkkala, T., and Lehtilä, K.: Trends and gradients in nutrient concentrations and loading in the Archipelago Sea, Northern Baltic, in 1970-1997, Estuar. Coast. Shelf S., 50, 153-171, https://doi.org/10.1006/ecss.1999.0568, 2000.

Hardisty, D. S., Riedinger, N., Planavsky, N. J., Asael, D., Andrén, T., Jørgensen, B. B., and Lyons, T. W.: A Holocene history of dynamic water column redox conditions in the 
Landsort Deep, Baltic Sea. Am. J. Sci., 316, 713-745, https://doi.org/10.2475/08.2016.01, 2016.

Hayes, J. M.: Factors controlling ${ }^{13} \mathrm{C}$ contents of sedimentary organic compounds: Principles and evidence, Mar. Geol., 113, 111-125, https://doi.org/10.1016/0025-3227(93)90153-M, 1993.

Heaton, T. H. E.: Isotopic studies of nitrogen pollution in the hydrosphere and atmosphere: A review, Chem. Geol., 59, 87-102, https://doi.org/10.1016/0168-9622(86)90059-X, 1986.

Heinrichs, H., Brumsack, H.-J., Lotfield, N., and König, N.: Verbessertes Druckaufschlußsystem für biologische und anorganische Materialien, Z. Pflanzenernähr. Bodenkd., 149, 350353, https://doi.org/10.1002/jpln.19861490313, 1986 (in German).

Helama, S., Meriläinen, J., and Tuomenvirta, H.: Multicentennial megadrought in northern Europe coincided with a global El Niño-Southern Oscillation drought pattern during Medieval Climate Anomaly, Geology, 37, 175-178, https://doi.org/10.1130/G25329A.1, 2009.

Helama, S., Vartiainen, M., Holopainen, J., Mäkelä, H. M., Kolström, T., and Meriläinen, J.: A paleotemperature record for the Finnish Lakeland based on microdensitometric variations in tree rings, Geochronometria, 41, 265-277, https://doi.org/10.2478/s13386-013-0163-0, 2014.

Helz, G. R. and Adelson, J. M.: Trace element profiles in sediments as proxies of dead zone history; rhenium compared to molybdenum, Environ. Sci. Technol., 47, 1257-1264, https://doi.org/10.1021/es303138d, 2013.

Helz, G. R., Miller, C. V., Charnock, J. M., Mosselmans, J. F. W., Patrick, R. A. D., Garner, D. D., and Vaughan, D. J.: Mechanism of molybdenum removal from the sea and its concentration in black shales: EXAFS evidence, Geochim. Coscmochim. Ac., 60, 3631-3642, https://doi.org/10.1016/0016-7037(96)00195-0, 1996.

Helz, G. R., Bura-Nakić, E., Mikac, N., and Ciglenečki, I.: New model for molybdenum behavior in euxinic waters, Chem. Geol., 284, 323-332, https://doi.org/10.1016/j.chemgeo.2011.03.012, 2011.

HERTTA database: The environmental and geographical information service, Finland's Environmental Administration, http: //www.syke.fi/fi-FI/Avoin_tieto/Ymparistotietojarjestelmat, last access: 22 August 2017.

Hjulström, E.: Transportation of detritus by moving water, in: Recent marine sediments, edited by: Trask, P. P., Dover, New York, 5-31, 1939.

Hoffmann, A. F., Soetaert, K., Middelburg, J. J., and Meysman, F. J. R.: AquaEnv: an aquatic acid-base modelling environment in R, Aquat. Geochem., 16, 507-546, https://doi.org/10.1007/s10498009-9084-1, 2010.

Hopmans, E. C., Weijers, J. W. H., Schefuss, E., Herfort, L., Sinninghe Damsté, J. S., and Schouten, S.: A novel proxy for terrestrial organic matter in sediments based on branched and isoprenoid tetraether lipids, Earth Planet. Sc. Lett., 24, 107-116, https://doi.org/10.1016/j.epsl.2004.05.012, 2004.

Hordoir, R., Höglund, A., Pemberton, P., and Schimanke, S.: Sensitivity of the overturning circulation of the Baltic Sea to climate change, a numerical experiment, Clim. Dynam., 50, 1425-1437, https://doi.org/10.1007/s00382-017-3695-9, 2017.
Jenny, J-P., Francus, P., Normandeau, A., Lapointe, F., Perga, M.-E., Ojala, A. E. K., Schimmelmann, A., and Zolitschka, B.: Global spread of hypoxia in freshwater ecosystems during the last three centuries is caused by rising local human pressure, Glob. Change Biol., 22, 1481-1489, https://doi.org/10.1111/gcb.13193, 2016 a.

Jenny, J.-P., Normandeau, A., Francus, P., Taranu, Z. E., GregoryEaves, I., Lapointe, F., Jautzy, J., Ojala, A. E. K., Dorioz, J.-M., Schimmelmann, A., and Zolitschka, B.: Urban point sources of nutrients were the leading cause for the initial spread of hypoxia across European lakes, P. Natl. Acad. Sci. USA, 113, 12655 12660, https://doi.org/10.1073/pnas.1605480113, 2016b.

Jilbert, T. and Slomp, C. P.: Rapid high-amplitude variability in Baltic Sea hypoxia during the Holocene, Geology, 41, 11831186, https://doi.org/10.1130/G34804.1, 2013.

Jilbert, T., Conley, D. J., Gustafsson, B. G., Funkey, C. P., and Slomp, C. P.: Glacio-isostatic control on hypoxia in a high-latitude shelf basin, Geology, 43, 427-430, https://doi.org/10.1130/G36454.1, 2015.

Jilbert, T., Asmala, E., Schröder, C., Tiihonen, R., Myllykangas, J.P., Virtasalo, J. J., Kotilainen, A., Peltola, P., Ekholm, P., and Hietanen, S.: Impacts of flocculation on the distribution and diagenesis of iron in boreal estuarine sediments, Biogeosciences, 15, 1243-1271, https://doi.org/10.5194/bg-15-1243-2018, 2018.

Jokinen, S. A., Virtasalo, J. J., Kotilainen, A. T., and Saarinen, T.: Varve microfabric record of seasonal sedimentation and bottom flow-modulated mud deposition in the coastal northern Baltic Sea, Mar. Geol., 366, 79-96, https://doi.org/10.1016/j.margeo.2015.05.003, 2015.

Jönsson, A., Danielsson, А., and Rahm, L.: Bottom type distribution based on wave friction velocity in the Baltic Sea, Cont. Shelf Res., 25, 419-435, https://doi.org/10.1016/j.csr.2004.09.011, 2005a.

Jönsson, A., Lindström, M., Carman, R., Mörth, C.-M., Meili, M., and Gustafsson, Ö.: Evaluation of the Stockholm Archipelago sediments, northwestern Baltic Sea Proper, as a trap for freshwater runoff organic carbon, J. Marine Syst., 56, 167-178, https://doi.org/10.1016/j.jmarsys.2004.11.001, 2005 b.

Jonsson, P., Wulff, R., and Carman R.: Laminated sediments in the Baltic - a tool for evaluating nutrient mass balances, Ambio, 19, 152-158, 1990.

Kabel, K., Moros, M., Porsche, C., Neumann, T., Adolphi, F., Andersen, T.J., Siegel, H., Gerth, M., Leipe, T., Jansen, E., and Damste, J. S. S.: Impact of climate change on the Baltic Sea ecosystem over the past 1000 years, Nat. Clim. Change, 2, 871874, https://doi.org/10.1038/nclimate1595, 2012.

Kaiser, J. and Arz, H. W.: Sources of sedimentary biomarkers and proxies with potential paleoenvironmental significance for the Baltic Sea, Cont. Shelf Res., 122, 102-119, https://doi.org/10.1016/j.csr.2016.03.020, 2016.

Karlsson, O. M., Jonsson, P. O., Lindgren, D., Malmaeus, J. M., and Stehn, A.: Indications of recovery from hypoxia in the Inner Stockholm Archipelago, Ambio, 39, 486-495, https://doi.org/10.1007/s13280-010-0079-3, 2010.

Kienast, S. S., Calvert, S. E., and Pedersen, T. F.: Nitrogen isotope and productivity variations along the northeast Pacific margin over the last $120 \mathrm{kyr}$ : Surface and subsurface palaeoceanography, Paleocenography, 17, 1055, https://doi.org/10.1029/2001PA000650, 2002. 
Kohzu, A., Imai, A., Ohkouchi, N., Fukushima, T., Kamiya, K., Komatsu, K., Tomioka, N., Kawasaki, N., Miura, S., and Satou, T.: Direct evidence for the alteration of ${ }^{13} \mathrm{C}$ natural abundances during early diagenesis in Lake Kasumigaura, Japan, Geochem. Geophy. Geosy., 12, Q10008, https://doi.org/10.1029/2011GC003532, 2011.

Kuosmanen, N., Seppä, H., Alenius, T., Bradshaw, R. H. W., Clear, J. L., Filimonova, L., Heikkilä, M., Renssen, H., Tallavaara, M., and Reitalu, T.: Importance of climate, forest fires and human population size in the Holocene boreal forest composition change in northern Europe, Boreas, 45, 688-702, https://doi.org/10.1111/bor.12183, 2016.

Lahtinen, R.: Turun historia, Turkuseura, Turku, 207 pp., 2014 (in Finnish).

Lehmann, M. F., Bernasconi, S. M., Barbieri, A., and McKenzie, J. A.: Preservation of organic matter and alteration of its carbon and nitrogen isotope composition during simulated and in situ early sedimentary diagenesis, Geochim. Coscmochim. Ac., 66, 35733584, https://doi.org/10.1016/S0016-7037(02)00968-7, 2002a.

Lehmann, A., Krauss, W., and Hinrichsen, H. H.: Effects of remote and local atmospheric forcing on circulation and upwelling in the Baltic Sea, Tellus A., 54, 299-316, https://doi.org/10.3402/tellusa.v54i3.12138, 2002b.

Leipe, T., Dippner, J. W., Hille, S., Voss, M., Christiansen, C., and Bartholdy, J.: Environmental changes in the central Baltic Sea during the past 1000 years: inferences from sedimentary records, hydrography and climate, Oceanologia, 50, 23-41, 2008.

Lenz, C., Jilbert, T., Conley, D. J., Wolthers, M., and Slomp, C. P.: Are recent changes in sediment manganese sequestration in the euxinic basins of the Baltic Sea linked to the expansion of hypoxia?, Biogeosciences, 12, 4875-4894, https://doi.org/10.5194/bg-12-4875-2015, 2015.

Leppäranta, M. and Myrberg, K.: Physical oceanography of the Baltic Sea, Springer Praxis, Berlin-Heidelberg-New York, 378 pp., 2009.

Levin, L. A., Ekau, W., Gooday, A. J., Jorissen, F., Middelburg, J. J., Naqvi, S. W. A., Neira, C., Rabalais, N. N., and Zhang, J.: Effects of natural and human-induced hypoxia on coastal benthos, Biogeosciences, 6, 2063-2098, https://doi.org/10.5194/bg6-2063-2009, 2009.

Lincoln, B. J., Rippeth, T. P., Lenn, Y.-D., Timmermans, M. L., Williams, J. W., and Bacon, S.: Wind-driven mixing at intermediate depths in an ice-free Arctic Ocean, Geophys. Res. Lett., 43, 9749-9756, https://doi.org/10.1002/2016GL070454, 2016.

Llansó, R. J.: Effects of hypoxia on estuarine benthos: the lower Rappahannock River (Chesapeake Bay), a case study, Estuar. Coast. Shelf S., 35, 491-515, https://doi.org/10.1016/S02727714(05)80027-7, 1992

Lougheed, B. C., Snowball, I., Moros, M., Kabel, K., Muscheler, R., Virtasalo, J. J., and Wacker, L.: Using an independent geochronology based on paleomagnetic secular variation (PSV) and atmospheric $\mathrm{Pb}$ deposition to date Baltic Sea sediments and infer ${ }^{14} \mathrm{C}$ reservoir age, Quaternary Sci. Rev., 42, 43-58, https://doi.org/10.1016/j.quascirev.2012.03.013, 2012.

Lougheed, B. C., Obrochta, S. P., Lenz, C., Mellström, A., Metcalfe, B., Muscheler, R., Reinholdsson, M., Snowball, I., and Zillén L.: Bulk sediment ${ }^{14} \mathrm{C}$ dating in an estuarine environment - How accurate can it be?, Paleoceanography, 32, 123-131, https://doi.org/10.1002/2016PA002960, 2017.
Luoto, T. P.: A Finnish chironomid- and chaoborid-based inference model for reconstructing past lake levels, Quaternary Sci. Rev., 28, 1481-1489, https://doi.org/10.1016/j.quascirev.2009.01.015, 2009.

Maankamara - DigiKP: Digital map database (Electronic resource), Geological Survey of Finland, available at: http://gtkdata.gtk.fi/ maankamara/, last access: 8 June 2017.

Mäkinen, J. and Saaranen, V.: Determination of post-glacial land uplift from the three precise levellings in Finland, J. Geodesy, 72, 516-529, https://doi.org/10.1007/s001900050191, 1998.

Mälkki, P., Koljonen, J., Valpasvuo, V., Julin, R., Jumppanen, K., and Juusti, T.: Saaristomeren virtaustutkimus, Virtaustutkimuksen neuvottelukunta, Turku, 265 pp., 1979 (in Finnish).

McClelland, J. W. and Valiela, I.: Linking nitrogen in estuarine producers to land-derived sources, Limnol. Oceanogr., 43, 577-585, https://doi.org/10.4319/lo.1998.43.4.0577, 1998.

Meier H. E. M., Andersson, H. C., Eilola, K., Gustafsson, B. G., Kuznetsov, I., Müller-Karulis, B., Neumann, T., and Savchuk, O. P.: Hypoxia in future climates: A model ensemble study for the Baltic Sea, Geophys. Res. Lett., 38, L24608, https://doi.org/10.1029/2011GL049929, 2011.

Meire, L., Soetaert, K. E. R., and Meysman, F. J. R.: Impact of global change on coastal oxygen dynamics and risk of hypoxia, Biogeosciences, 10, 2633-2653, https://doi.org/10.5194/bg-102633-2013, 2013.

Meyers, P. A.: Preservation of elemental and isotopic source identification of sedimentary organic matter, Chem. Geol., 114, 289302, https://doi.org/10.1016/0009-2541(94)90059-0, 1994.

Meyers, P. A.: Organic geochemical proxies of paleoceanographic, paleolimnologic, and paleoclimatic processes, Org. Geochem., 27, 213-250, https://doi.org/10.1016/S0146-6380(97)00049-1, 1997.

Meyers, P. A.: Applications of organic geochemistry to paleolimnological reconstructions: a summary of examples from the Laurentian Great Lakes, Org. Geochem., 34, 261-289, https://doi.org/10.1016/S0146-6380(02)00168-7, 2003.

Middelburg, J. J. and Levin, L. A.: Coastal hypoxia and sediment biogeochemistry, Biogeosciences, 6, 1273-1293, https://doi.org/10.5194/bg-6-1273-2009, 2009.

Mogollón, J. M., Dale, A. W., L'Heureux, I., and Regnier, P.: Impact of seasonal temperature and pressure changes on methane gas production, dissolution, and transport in unfractured sediments, J. Geophys. Res., 116, G03031, https://doi.org/10.1029/2010JG001592, 2011.

Mort, H. P., Slomp, C. P., Gustafsson, B. G., and Andersen, T. J.: Phosphorus recycling and burial in Baltic Sea sediments with contrasting redox conditions, Geochim. Coscmochim. Ac., 74, 1350-1362, https://doi.org/10.1016/j.gca.2009.11.016, 2010.

Müller, A. and Mathesius, U.: The palaeoenvironments of coastal lagoons in the southern Baltic Sea, I, The application of sedimentary $\mathrm{C}_{\mathrm{org}} / \mathrm{N}$ ratios as source indicators of organic matter, Palaeogeogr. Palaeocl., 145, 1-16, https://doi.org/10.1016/S0031-0182(98)00094-7, 1999.

Müller, P. J.: C / $\mathrm{N}$ ratios in Pacific deep-sea sediments: Effect of inorganic ammonium and organic nitrogen compounds sorbed by clays, Geochim. Coscmochim. Ac., 41, 765-776, https://doi.org/10.1016/0016-7037(77)90047-3, 1977.

Ning, W., Tang, J., and Filipsson, H. L.: Long-term coastal openness variation and its impact on sediment grain-size distribution: 
a case study from the Baltic Sea, Earth Surf. Dynam., 4, 773780, https://doi.org/10.5194/esurf-4-773-2016, 2016.

Ning, W., Nielsen, A. B., Norbäck Ivarsson, L., Jilbert, T., Åkesson, C. M., Slomp, C. P., Andrén, E., Broström, A., and Filipsson, H. L.: Anthropogenic and climatic impacts on a coastal environment in the Baltic Sea over the last 1000 years, Anthropocene, 21, 6679, https://doi.org/10.1016/j.ancene.2018.02.003, 2018.

Noordmann, J., Weyer, S., Montoya-Pino, C., Dellwig, O., Neubert, N., Eckert, S., Paetzel, M., and Böttcher, M. E.: Uranium and molybdenum isotope systematics in modern euxinic basins: Case studies from the central Baltic Sea and the Kyllaren fjord (Norway), Chem. Geol., 396, 182-195, https://doi.org/10.1016/j.chemgeo.2014.12.012, 2015.

O'Connor, A. E., Luek, J. L., McIntosh, H., and Beck, A. J.: Geochemistry of redox-sensitive trace elements in a shallow subterranean estuary, Mar. Chem., 172, 70-81, https://doi.org/10.1016/j.marchem.2015.03.001, 2015.

Ojala, A. E. K. and Alenius, T.: 10000 years of interannual sedimentation recorded in the Lake Nautajärvi (Finland) clastic-organic varves, Palaeogeogr. Palaeocl., 219, 285-302, https://doi.org/10.1016/j.palaeo.2005.01.002, 2005.

Pamatmat, M. M.: Oxygen consumption by the seabed, VI, Seasonal cycle of chemical oxidation and respiration in Puget Sound, Int. Rev. Hydrobiol., 56, 769-793, https://doi.org/10.1002/iroh.19710560505, 1971.

Papadomanolaki, N. M., Dijkstra, N., Van Helmond, N. A. G. M., Hagens, M., Bauersachs, T., Kotthoff, U., Sangiorgi, F., and Slomp, C. P.: Controls on the onset and termination of past hypoxia in the Baltic Sea, Palaeogeogr. Palaeocl., 490, 347-354, https://doi.org/10.1016/j.palaeo.2017.11.012, 2018.

Passow, U.: Switching perspectives: Do mineral fluxes determine particulate organic carbon fluxes or vice versa?, Geochem. Geophy. Geosy., 5, Q04002, https://doi.org/10.1029/2003GC000670, 2004

Passow, U. and De La Rocha, C.: Accumulation of mineral ballast on organic aggregates, Global Biogeochem. Cy., 20, GB1013, https://doi.org/10.1029/2005GB002579, 2006.

Pedersen, T. F. and Calvert, S. E.: Anoxia versus productivity: What controls the formation of organic-rich sediments and sedimentary rocks?, Bull. Am. Assoc. Petrol. Geol., 74, 454-466, 1990.

Peltola, P., Virtasalo, J. J., Öberg, T., and Åström, M.: Geochemistry of surface sediments in the Archipelago Sea, SW Finland: a multiparameter and multivariate study, Environ. Earth Sci., 62, 725-734, https://doi.org/10.1007/s12665-010-0561-z, 2011.

Perdue, E. M. and Koprivnjak, J.-F.: Using the $\mathrm{C} / \mathrm{N}$ ratio to estimate terrigenous inputs of organic matter to aquatic environments, Estuar. Coast. Shelf S., 73, 65-72, https://doi.org/10.1016/j.ecss.2006.12.021, 2007.

Persson, J. and Jonsson, P.: Historical development of laminated sediments - an approach to detect soft sediment ecosystem changes in the Baltic Sea, Mar. Pollut. Bull., 40, 122-134, https://doi.org/10.1016/S0025-326X(99)00180-0, 2000.

Peters, K. E., Walters, C. C., and Moldowan, J. M.: The biomarker guide: Biomarkers and isotopes in the petroleum exploration and Earth history, Second edition, Cambridge University Press, Cambridge, 1155 pp., 2005.

Peterse, F., Kim, J.-H., Schouten, S., Klitgaard Kristensen, D., Koç, N., and Sinninghe Damsté, J. S.: Constraints on the application of the MBT/CBT paleothermometer in high latitude en- vironments (Svalbard, Norway), Org. Geochem., 40, 692-699, https://doi.org/10.1016/j.orggeochem.2009.03.004, 2009.

Piva, A., Asioli, A., Schneider, R. R., Trincardi, F., Andersen, N., Colmenero-Hidalgo, E., Dennielou, B., Flores, J.-A., and Vigliotti, L.: Climatic cycles as expressed in sediments of the PROMESS1 borehole PRAD1-2, central Adriatic, for the last 370 ka: 1. Integrated stratigraphy, Geochem. Geophy. Geosy., 9, Q01R01, https://doi.org/10.1029/2007GC001713, 2008.

Puttonen, I., Mattila, J., Jonsson, P., Karlsson, O. M., Kohonen, T., Kotilainen, A., Lukkari, K., Malmaeus, J. M., and Rydin, E.: Distribution and estimated release of sediment phosphorus in the northern Baltic Sea archipelagos, Estuar. Coast. Shelf S., 145, 9-21, https://doi.org/10.1016/j.ecss.2014.04.010, 2014.

Rabalais, N. N., Díaz, R. J., Levin, L. A., Turner, R. E., Gilbert, D., and Zhang, J.: Dynamics and distribution of natural and human-caused hypoxia, Biogeosciences, 7, 585-619, https://doi.org/10.5194/bg-7-585-2010, 2010.

Rabalais, N. N., Cai, W., Carstensen, J., Conley, D. J., Fry, B., Hu, X., Quinones-Rivera, Z., Rosenberg, R., Slomp, C. P., Turner, R. E., Voss, M., Wissel, B., and Zhang, J.: Eutrophication-driven deoxygenation in the coastal ocean, Oceanography, 27, 172-183, https://doi.org/10.5670/oceanog.2014.21, 2014.

Renberg, I., Brännvall, M.-L., Bindler, R., and Emteryd, O.: Stable isotopes and lake sediments - a useful combination for the study of atmospheric lead pollution history, Sci. Total Environ., 292, 45-54, https://doi.org/10.1016/S0048-9697(02)00032-3, 2002.

Ronkainen, I.: Long-term changes in Baltic Sea ice conditions, M.S. thesis, Department of Physics, University of Helsinki, Finland, 73 pp., 2013.

Rooze, J., Egger, M., Tsandev, I., and Slomp, C. P.: Iron-dependent anaerobic oxidation of methane in coastal surface sediments: Potential controls and impact, Limnol. Oceanogr., 61, S267-S282, https://doi.org/10.1002/lno.10275, 2016.

Rößler, D., Moros, M., and Lemke, W.: The Littorina transgression in the southwestern Baltic Sea: new insights based on proxy methods and radiocarbon dating of sediment sediment cores, Boreas, 40, 231-241, https://doi.org/10.1111/j.15023885.2010.00180.x, 2011.

Rost, B., Riebesell, U., and Burkhardt, S.: Carbon acquisition of bloom-forming marine phytoplankton, Limnol. Oceanogr., 48, 55-67, https://doi.org/10.4319/lo.2003.48.1.0055, 2003.

Rutgersson, A., Jaagus, J., Schenk, F., and Stendel, M.: Observed changes and variability of atmospheric parameters in the Baltic Sea region during the last 200 years, Clim. Res., 61, 177-190, https://doi.org/10.3354/cr01244, 2014.

Saarni, S., Saarinen, T., and Lensu, A.: Organic lacustrine sediment varves as indicators of past precipitation changes: a 3000-year climate record from Central Finland, J. Paleolimnol., 53, 401413, https://doi.org/10.1007/s10933-015-9832-8, 2015.

Saarni, S., Muschitiello, F., Weege, S., Brauer, A., and Saarinen, T.: A late Holocene record of solar-forced atmospheric blocking variability over Northern Europe inferred from varved lake sediments of Lake Kuninkaisenlampi, Quaternary Sci. Rev., 154, 100-110, https://doi.org/10.1016/j.quascirev.2016.10.019, 2016.

Savage, C., Leavitt, P. R., and Elmgren, R.: Effects of land use urbanization, and climate variability on coastal eutrophication in the Baltic Sea, Limnol. Oceanogr., 55, 1033-1046, https://doi.org/10.4319/lo.2010.55.3.1033, 2010. 
Savrda, C. E. and Bottjer, D. J.: Trace-fossil model for reconstruction of paleo-oxygenation in bottom waters, Geology, 14, 3-6, https://doi.org/10.1130/00917613(1986)14<3:TMFROP>2.0.CO;2, 1986.

Savrda, C. E. and Bottjer, D. J.: Oxygen-related biofacies in marine strata: an overview and update, in: Modern and ancient continental shelf anoxia, edited by: Tyson, R. V. and Pearson, T. H., Geol. Soc. London Spec. Publ., 58, 201-219, https://doi.org/10.1144/GSL.SP.1991.058.01.14, 1991.

Sawicka, J. E. and Brüchert, V.: Annual variability and regulation of methane and sulfate fluxes in Baltic Sea estuarine sediments, Biogeosciences, 14, 325-339, https://doi.org/10.5194/bg14-325-2017, 2017.

Scheiderich, K., Helz, G. R., and Walker, R. J.: Century-long record of Mo isotopic composition in sediments of a seasonally anoxic estuary (Chesapeake Bay), Earth Planet. Sc. Lett., 289, 189-197, https://doi.org/10.1016/j.eps1.2009.11.008, 2010.

Schimanke, S., Meier, H. E. M., Kjellström, E., Strandberg, G., and Hordoir, R.: The climate in the Baltic Sea region during the last millennium simulated with a regional climate model, Clim. Past, 8, 1419-1433, https://doi.org/10.5194/cp-8-1419-2012, 2012.

Schlitzer, R.: Ocean Data View, available at: http://odv.awi.de (last access: 10 August 2017), 2017.

Scholz, F., McManus, J., and Sommer, S.: The manganese and iron shuttle in a modern euxinic basin and implications for molybdenum cycling at euxinic ocean margins, Chem. Geol., 355, 56-68, https://doi.org/10.1016/j.chemgeo.2013.07.006, 2013.

Schouten, S., Hopmans, E. C., and Sinninghe Damsté, J. S.: The organic geochemistry of glycerol dialkyl glycerol tetraether lipids: A review, Org. Geochem., 54, 19-61, https://doi.org/10.1016/j.orggeochem.2012.09.006, 2013.

Scott, C. and Lyons, T. W.: Contrasting molybdenum cycling and isotopic properties in euxinic versus noneuxinic sediments and sedimentary rocks: Refining the paleoproxies, Chem. Geol., 324-325, 19-27, https://doi.org/10.1016/j.chemgeo.2012.05.012, 2012.

Seinä, A.: Extent of ice cover 1961-1990 and restrictions to navigation 1981-1990 along the Finnish coast, Finnish Marine Research., 262, 3-34, 1994.

Slomp, C. P., Mort, H. P., Jilbert, T., Reed, D. C., Gustafsson, B. G., and Wolthers, M.: Coupled dynamics of iron and phosphorus in sediments of an oligotrophic basin and the impact of anaerobic oxidation of methane, PLoS One, 8, e62386, https://doi.org/10.1371/journal.pone.0062386, 2013.

Sinninghe Damsté, J. S., Ossebaar, J., Abbas, B., Schouten, S., and Verschuren, D.: Fluxes and distribution of tetraether lipids in an equatorial African lake: Constraints on the application of the $\mathrm{TEX}_{86}$ palaeothermometer and BIT index in lacustrine settings, Geochim. Coscmochim. Ac., 73, 4232-4249, https://doi.org/10.1016/j.gca.2009.04.022, 2009.

Spofforth, D. J. A., Pälike, H., and Green, D.: Paleogene record of elemental concentrations in sediments from the Arctic Ocean obtained by XRF analyses, Paleoceanography, 23, PA1S09, https://doi.org/10.1029/2007PA001489, 2008.

Steffen, W., Broadgate, W., Deutsch, L., Gaffney, O., and Ludwig, C.: The trajectory of the Anthropocene: The Great Acceleration, The Anthropocene Review, 2, 81-98, https://doi.org/10.1177/2053019614564785, 2015.
Stroeven, A. P., Hättestrand, C., Kleman, J., Heyman, J., Fabel, D., Fredin, O., Goodfellow, B. W., Harbor, J. M., Jansen, J. D., Olsen, L., Caffee, M. W., Fink, D., Lundqvist, J., Rosqvist, G. C., Strömberg, B., and Jansson, K. N.: Deglaciation of Fennoscandia, Quaternary Sci. Rev., 147, 91-121, https://doi.org/10.1016/j.quascirev.2015.09.016, 2016.

Struck, U., Emeis, K.-C., Voss, M., Christiansen, C., and Kunzendorf, H.: Records of southern and central Baltic Sea eutrophication in $\delta^{13} \mathrm{C}$ and $\delta^{15} \mathrm{~N}$ of sedimentary organic matter, Mar. Geol., 164, 157-171, https://doi.org/10.1016/S0025-3227(99)00135-8, 2000.

Sulu-Gambari, F., Roepert, A., Jilbert, T., Mathilde, H., Meysman, F. J. R., and Slomp, C. P.: Molybdenum dynamics in sediments of a seasonally-hypoxic coastal marine basin, Chem. Geol., 466, 627-640, https://doi.org/10.1016/j.chemgeo.2017.07.015, 2017.

Suomela, J.: Meren kuormitus ja tila Saaristomerellä ja Ahvenanmaalla, Varsinais-Suomen elinkeino-, liikenne-, ja ympäristökeskuksen julkaisuja, 6, 1-117, 2011 (in Finnish).

Thomsen, E. and Vorren, T. O.: Pyritization of tubes and burrows from Late Pleistocene continental shelf sediments off North Norway, Sedimentology, 31, 481-492, https://doi.org/10.1111/j.1365-3091.1984.tb01814.x, 1984.

Thunell, R. C., Sigman, D. M., Muller-Karger, F., Astor, Y., and Varela, R.: Nitrogen isotope dynamics of the Cariaco Basin, Venezuela, Global Biogeochem. Cy., 18, GB3001, https://doi.org/10.1029/2003GB002185, 2004.

Tiljander, M., Saarnisto, M., Ojala, A. E. K., and Saarinen, T.: A 3000-year palaeoenvironmental record of annually laminated sediment of Lake Korttajärvi, central Finland, Boreas, 26, 566577, https://doi.org/10.1111/j.1502-3885.2003.tb01236.x, 2003.

Tuomenvirta, H., Drebs, A., Førland, E., Tveito, O. E., Alexandersson, H., Laursen, E. V., Jónsson, T., and Gama, J.: nordklimdata1: Dataset for climate analysis with data from the Nordic region, $\mathrm{R}$ package, version 1.2, 2015.

Tuovinen, N., Virtasalo, J. J., and Kotilainen, A. T.: Holocene diatom stratigraphy in the Archipelago Sea, northern Baltic Sea, J. Paleolimnol., 40, 793-807, https://doi.org/10.1007/s10933-0089199-1, 2008.

Vahtera, E., Conley, D. J., Gustafsson, B. G., Kuosa, H., Pitkänen, H., Savchuk, O. P., Tamminen, T., and Viitasalo, M.: Internal ecosystem feedbacks enhance nitrogen-fixing cyanobacteria blooms and complicate management in the Baltic Sea, Ambio, 36, 186-194, https://doi.org/10.1579/00447447(2007)36[186:IEFENC]2.0.CO;2, 2007.

Väliranta, M., Korhola, A., Seppä, H., Tuittila, E.-S., SarmajaKorhonen, K., Laine, J., and Alm, J.: High-resolution reconstruction of wetness dynamics in a southern boreal raised bog, Finland, during the late Holocene: a quantitative approach, Holocene, 17, 1093-1107, https://doi.org/10.1177/0959683607082550, 2007.

Van Helmond, N. A. G. M., Krupinski, N. B. Q., Lougheed, B. C., Obrochta, S. P., Andrén, T., and Slomp, C. P.: Seasonal hypoxia was a natural feature of the coastal zone in the Little Belt Denmark, during the past 8 ka, Mar. Geol., 387, 45-57, https://doi.org/10.1016/j.margeo.2017.03.008, 2017.

Vaquer-Sunyer, R. and Duarte, C. M.: Thresholds of hypoxia for marine biodiversity, P. Natl. Acad. Sci. USA, 17, 1788-1797, https://doi.org/10.1073/pnas.0803833105, 2008. 
Venkatesan, M. I. and Kaplan, J. R.: The lipid geochemistry of Antarctic marine sediments: Bransfield Strait, Mar. Chem., 21, 347-375, https://doi.org/10.1016/0304-4203(87)90056-9, 1987.

Verburg, P.: The need to correct for the Suess effect in the application of $\delta^{13} \mathrm{C}$ in sediment of autotrophic Lake Tanganyika, as a productivity proxy in the Anthropocene, J. Paleolimnol., 37, 591-602, https://doi.org/10.1007/s10933-006-9056-z, 2007.

Virtasalo, J. J., Kohonen, T., Vuorinen, I., and Huttula, T.: Sea bottom anoxia in the Archipleago Sea, northern Baltic Sea - Implications for phosphorus remineralization at the sediment surface, Mar. Geol., 224, 103-122, https://doi.org/10.1016/j.margeo.2005.07.010, 2005.

Virtasalo, J. J., Kotilainen, A. T., and Gingras, M. K.: Trace fossils as indicators of environmental change in Holocene sediments of the Archipelago Sea, northern Baltic Sea, Palaeogeogr. Palaeocl., 240, 453-467, https://doi.org/10.1016/j.palaeo.2006.02.010, 2006.

Virtasalo, J. J., Kotilainen, A. T., Räsänen, M. E., and Ojala, A. E. K.: Late-glacial and post-glacial deposition in a large, low relief, epicontinental basin: the northern Baltic Sea, Sedimentology, 54, 1323-1344, https://doi.org/10.1111/j.1365-3091.2007.00883.x, 2007.

Virtasalo, J. J., Bonsdorff, E., Moros, M., Kabel, K., Kotilainen, A. T., Ryabchuk, D., Kallonen, A., and Hämäläinen, K.: Ichnological trends along an open-water transect across a large marginalmarine epicontinental basin, the modern Baltic Sea, Sediment. Geol., 241, 40-51, https://doi.org/10.1016/j.sedgeo.2011.09.010, 2011a.

Virtasalo, J. J., Leipe, T., Moros, M., and Kotilainen, A. T.: Physicochemical and biological influences on sedimentaryfabric formation in a salinity and oxygen-restricted semienclosed sea: Gotland Deep, Baltic Sea, Sedimentology, 58, 352375, https://doi.org/10.1111/j.1365-3091.2010.01166.x, 2011 b.

Virtasalo, J. J., Hämäläinen, J., and Kotilainen, A. T.: Toward a standard stratigraphical classification practice for the Baltic Sea sediments: the CUAL approach, Boreas, 43, 924-938, https://doi.org/10.1111/bor.12076, 2014.
Voss, M. and Struck, U.: Stable nitrogen and carbon isotopes as indicator of eutrophication of the Oder river (Baltic Sea), Mar. Chem., 59, 35-49, https://doi.org/10.1016/S03044203(97)00073-X, 1997.

Voss, M., Altabet, M. A., and Von Bodungen, B.: $\delta^{15} \mathrm{~N}$ in sedimenting particles as indicator of euphotic zone processes, Deep-Sea Res., 43, 33-47, https://doi.org/10.1016/0967-0637(95)00099-2, 1996.

Voss, M., Larsen, B., Leivuori, M., and Vallius, H.: Stable isotope signals of eutrophication in Baltic Sea sediments, J. Marine Syst., 25, 287-298, https://doi.org/10.1016/S0924-7963(00)00022-1, 2000.

Voss, M., Emeis, K.-C., Hille, S., Neumann, T, and Dippner, J. W.: Nitrogen cycle of the Baltic Sea from an isotopic perspective, Global Biogeochem. Cy., 19, GB3001, https://doi.org/10.1029/2004GB002338, 2005.

Weijers, J. W. H., Schouten, S., Spaargaren, O. C., and Sinninghe Damsté, J. S.: Occurrence and distribution of tetraether membrane lipids in soils: Implications for the use of the $\mathrm{TEX}_{86}$ proxy and the BIT index, Org. Geochem., 37, 1680-1693, https://doi.org/10.1016/j.orggeochem.2006.07.018, 2006.

Wetzel, A.: Ecologic interpretation of deep-sea trace fossil communities, Palaeogeogr. Palaeocl., 85, 47-69, https://doi.org/10.1016/0031-0182(91)90025-M, 1991.

Zhang, J., Gilbert, D., Gooday, A. J., Levin, L., Naqvi, S. W. A., Middelburg, J. J., Scranton, M., Ekau, W., Peña, A., Dewitte, B., Oguz, T., Monteiro, P. M. S., Urban, E., Rabalais, N. N., Ittekkot, V., Kemp, W. M., Ulloa, O., Elmgren, R., Escobar-Briones, E., and Van der Plas, A. K.: Natural and human-induced hypoxia and consequences for coastal areas: synthesis and future development, Biogeosciences, 7, 1443-1467, https://doi.org/10.5194/bg7-1443-2010, 2010.

Zillén, L. and Conley, D. J.: Hypoxia and cyanobacteria blooms - are they really natural features of the late Holocene history of the Baltic Sea?, Biogeosciences, 7, 2567-2580, https://doi.org/10.5194/bg-7-2567-2010, 2010.

Zillén, L., Lenz, C., and Jilbert, T.: Stable lead $(\mathrm{Pb})$ isotopes and concentrations - A useful independent dating tool for Baltic Sea sediments, Quat. Geochronol., 8, 41-45, https://doi.org/10.1016/j.quageo.2011.11.001, 2012. 